\title{
Cereal and Confectionary Packaging: Background, Application and Shelf-Life Extension
}

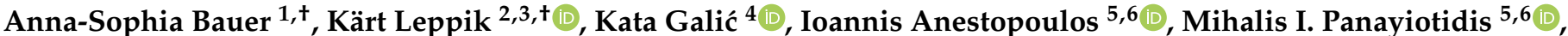 \\ Sofia Agriopoulou ${ }^{7}\left(\mathbb{D}\right.$, Maria Milousi ${ }^{8}$, Ilke Uysal-Unalan ${ }^{9,10}$, Theodoros Varzakas ${ }^{7, *(\mathbb{D}}$ and Victoria Krauter $1, * \mathbb{( 1 )}$
}

check for

updates

Citation: Bauer, A.-S.; Leppik, K.;

Galić, K.; Anestopoulos, I.;

Panayiotidis, M.I.; Agriopoulou, S. Milousi, M.; Uysal-Unalan, I.;

Varzakas, T.; Krauter, V. Cereal and

Confectionary Packaging:

Background, Application and

Shelf-Life Extension. Foods 2022, 11,

697. https://doi.org/10.3390/

foods11050697

Academic Editor: Haiying Cui

Received: 5 February 2022

Accepted: 15 February 2022

Published: 26 February 2022

Publisher's Note: MDPI stays neutral with regard to jurisdictional claims in published maps and institutional affiliations.

Copyright: (c) 2022 by the authors Licensee MDPI, Basel, Switzerland. This article is an open access article distributed under the terms and conditions of the Creative Commons Attribution (CC BY) license (https:// creativecommons.org/licenses/by/ $4.0 /)$.
1 Packaging and Resource Management, Department Applied Life Sciences, FH Campus Wien, 1030 Vienna, Austria; anna-sophia.bauer@fh-campuswien.ac.at

2 Center of Food and Fermentation Technologies, Akadeemia tee 15a, 12618 Tallinn, Estonia; kart@tftak.eu

3 Department of Chemistry and Biotechnology, School of Science, Tallinn University of Technology, Ehitajate tee 5, 19086 Tallinn, Estonia

4 Faculty of Food Technology and Biotechnology, University of Zagreb, HR10000 Zagreb, Croatia; kata.galic@pbf.unizg.hr

5 Department of Cancer Genetics, Therapeutics \& Ultrastructural Pathology, The Cyprus Institute of Neurology \& Genetics, AyiosDometios, Nicosia 2371, Cyprus; ioannisa@cing.ac.cy (I.A.); mihalisp@cing.ac.cy (M.I.P.)

6 The Cyprus School of Molecular Medicine, AyiosDometios, Nicosia 2371, Cyprus

7 Department of Food Science and Technology, University of the Peloponnese, Antikalamos, 24100 Kalamata, Greece; s.agriopoulou@uop.gr

8 Department of Chemical Engineering, University of Western Macedonia, 50100 Kozani, Greece; mmilousi@uowm.gr

9 Department of Food Science, Aarhus University, Agro Food Park 48, 8200 Aarhus, Denmark; iuu@food.au.dk

10 CiFOOD—Center for Innovative Food Research, Aarhus University, Agro Food Park 48, 8200 Aarhus, Denmark

* Correspondence: t.varzakas@uop.gr (T.V.); victoria.krauter@fh-campuswien.ac.at (V.K.); Tel.: +43-1-606-68-77-3592 (V.K.)

+ These authors contributed equally to this work.

Abstract: In both public and private sectors, one can notice a strong interest in the topic of sustainable food and packaging. For a long time, the spotlight for optimization was placed on well-known examples of high environmental impacts, whether regarding indirect resource use (e.g., meat, dairy) or problems in waste management. Staple and hedonistic foods such as cereals and confectionary have gained less attention. However, these products and their packaging solutions are likewise of worldwide ecologic and economic relevance, accounting for high resource input, production amounts, as well as food losses and waste. This review provides a profound elaboration of the status quo in cereal and confectionary packaging, essential for practitioners to improve sustainability in the sector. Here, we present packaging functions and properties along with related product characteristics and decay mechanisms in the subcategories of cereals and cereal products, confectionary and bakery wares alongside ready-to-eat savories and snacks. Moreover, we offer an overview to formerly and recently used packaging concepts as well as established and modern shelf-life extending technologies, expanding upon our knowledge to thoroughly understand the packaging's purpose; we conclude that a comparison of the environmental burden share between product and packaging is necessary to properly derive the need for action(s), such as packaging redesign.

Keywords: food packaging; cereals; confectionary; bakery; food quality; shelf-life; sustainable packaging; active and intelligent packaging; modified atmosphere packaging; vacuum packaging

\section{Introduction}

Over the past decades, global awareness about environmental, social and economic sustainability challenges, as well as the need for immediate action to limit their negative 
short- and long-term impacts, has risen considerably. With regard to environmental sustainability, challenges encompass, but are not limited to, the use of resources, land, water, energy, and generation of associated emissions and waste. In order to facilitate the transition towards a sustainable future, several (inter)national goals, commitments, and legal bases have already been initiated or applied. These include, for instance, the Paris Agreement on climate change and the United Nations Sustainable Development Goals (SDGs) on a global scale, the European Green Deal including the New Circular Economy Action Plan, as well as the Farm to Fork Strategy on European level and numerous implementations into national law systems [1-6].

Regarding food, it is well-agreed in the scientific community and beyond, that a great share of negative environmental impacts such as global anthropogenic greenhouse gas emissions or waste originate from food systems [7-9]. These systems are defined as the whole of actors and activities involved, from production to the disposal of food products of different origins, as well as herewith associated natural, social, and economic environments [10]. Moreover, they are composed of subsystems (e.g., farming) and connected to other systems (e.g., energy). A complex network in which changes (e.g., policies) made in one sector may also affect others. Against this background, different international efforts have been taken to achieve sustainable food systems, which will provide present and future generations with a secure supply of safe food [11].

Packaging is strongly associated with food, allowing, amongst other functions, containment, protection, and transportation of contents, and thus can be seen as an integral part of food systems [12,13]. Nevertheless, nowadays it is the subject of intense debates and even stricter legal requirements, mainly due to massive circularity gaps including, for example, unsatisfactory end-of-life scenarios such as limited recyclability or (marine) litter $[14,15]$. However, the simple omission of packaging is hardly possible, since a well-chosen packaging system frequently shows positive (indirect) effects on the total environmental sustainability of a food system by, for example, reducing food losses and food waste or increasing transport efficiency [16]. Therefore, when aiming at developing sustainable packaging solutions, it is important to apply a holistic and interdisciplinary approach over the whole life cycle of both food and its corresponding packaging [17].

Since packaging offers a service to the food product and does not fulfil an end in itself, it is often worth starting a packaging development or a redesign process from the food perspective. By gaining profound knowledge of the food product itself, together with the intrinsic and extrinsic factors that affect quality along the food supply chain, further packaging requirements can be defined and considered in the innovation process $[12,13,17]$.

Due to their high environmental impact, the focus of research and development activities is often on (animal protein-rich) foods such as meat or milk [18-20]. Despite their high nutritional value that shouldn't be underestimated, cereal and confectionary products are rather underrepresented, regarding their impact in health but also in economic and environmental sustainability [21-27]. For instance, about 50\% of daily required carbohydrates are consumed through bread in industrialized countries. Further, cereals are also an important source of proteins, minerals, and trace elements [28]. Expressed in figures, retail sales of bread alone were expected to reach about 92 billion euros in Europe in 2021 [29]. On the other hand, confectionary products reached a production volume of 14.7 million tons with an annual turnover of 60 billion euros along with an export value of 9.2 euros and an import value of two billion euros in Europe (EU28) in 2019 [30].

In more detail, the present review aims at building a comprehensive basis for future sustainable packaging development activities in the area of cereal and confectionary products by:

- $\quad$ Presenting relevant information on packaging functions and properties of packaging materials,

- $\quad$ detailing product group specific decay mechanisms and frequently used packaging solutions,

- $\quad$ and highlighting packaging-related shelf-life extension technologies. 
The text is therefore structured as follows: After the introduction, a general background on food packaging is discussed, followed by product group specific decay mechanisms and packaging solutions. Finally, packaging measures that can extend the shelf-life are presented (see also Figure 1).

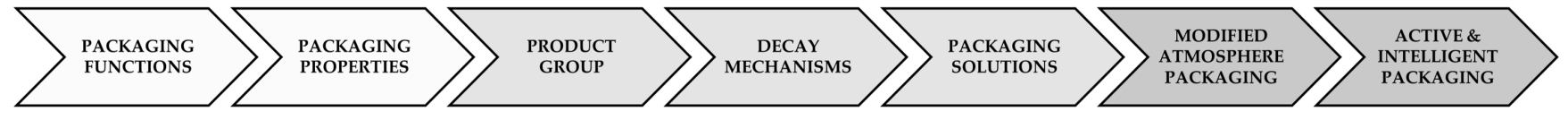

Figure 1. Outline of discussed topics, based on the review's aims.

\section{Packaging}

\subsection{Packaging Functions}

No matter how diverse individual products and packaging solutions may be on the market, it is well-agreed in relevant literature that the main functions of packaging can be broken down into a few. Next to the concept of primary and secondary functions, where the former describes in particular the technical functions like storage and transport, and the latter describes functions related to e.g., communication, a more holistic concept is frequently mentioned in the packaging literature. This concept describes the four basic functions of food packaging as (i) containment, (ii) protection, (iii) convenience, and (iv) communication [12,13,31-33].

Although the containment function is often overlooked, it can be considered one of the most essential, since it prevents product loss and contamination and facilitates storage, transportation, and distribution. There are only a few exceptions, where containment and thus packaging is not needed. Such examples are relatively large, chunky products that are often regionally produced and consumed within a short period of time or that show long shelf-life $[12,13,31]$.

The protection function is often recognised as well as highlighted and can be indeed considered as the most important aspect of packaging. It limits or excludes intrinsic as well as extrinsic physical, chemical, and biological factors that may have negative influences on the quality of the respective food product. In the best case, the packaging is even capable of extending the shelf-life of the product. Therefore, it is of upmost importance to match the food product's properties and requirements along the supply chain with packaging to achieve optimal results. Both under- and over-packaging should be avoided since this may result, on one hand, in food losses or waste and, on the other hand, in excessive packaging $[12,13,31]$.

Further, the convenience function refers to the practical aspects or user-friendliness of packaging. As an example, easy-to-open or -empty, microwave- or heat-able, resealable, or portion packaging can be named. These features are more and more implemented in package designs, since they allow to specifically address target groups (e.g., children, elderly, single-households, on-the-go lifestyle) and therefore frequently influence the market success of a product $[12,13,31]$.

Last but not least, the communication function allows for information transfer and marketing. While the former allows to display legally required (e.g., product name, ingredients, shelf-life), necessary (e.g., barcodes), or voluntary (e.g., certificates, cooking recipe) information, the latter enables to transfer an often unique brand image (e.g., form, colour, shape), which may be of great recognition value $[12,13,31]$.

It is worth mentioning that a successful package on the market does not only need a strong product in terms of quality but also an effective packaging, which in a clever way combines the above described four functions of containment, protection, convenience and communication. Otherwise, it may result in a short-term success (weak product and effective packaging), a situation where the potential is not achieved (strong product and ineffective packaging), or even failure (weak product and ineffective packaging) [31]. 


\subsection{Packaging Properties}

From a technical point of view, the functions containment and protection are closely linked to the right selection of packaging materials which consequently poses a key decision in the development process. The available material classes cover mainly glass, metal, paper/board, (bio)plastic, as well as composite materials (laminated, coextruded, blended). Composites can consist of two or more components combined to form, for example, multilayer materials (e.g., plastic-coated cardboard) which frequently show superior functional properties (e.g., barrier) and reduced weight [31], but on the downside also reduced recyclability $[34,35]$. Touching upon the topic of recyclability, many packaging solutions face obstacles, if it is at the stage of collection, sorting, or in general limited technical recyclability. Not even the use of mono-materials guarantees actual recycling, as it is the case for PET trays versus PET bottles (bottles are highly likely to be recycled). On the other hand, specific combinations of compatible materials, even high barrier films, for example, metallized polyolefins, might be considered recyclable in the appropriate infrastructure [36,37]. Summing up, it can be stated that each of the named materials show advantages and disadvantages (see Table 1) and the decision for a specific material must be based on the prevailing requirements (e.g., product, supply chain, use, end-of-life). Support is often provided by material specifications and declaration of compliance documents. However, it is recommended to test the materials in question under respective conditions by means of a field or laboratory test. This ensures that deviations from the target value can be recognized at an early stage in the development process $[12,13,31,38,39]$.

Table 1. Overview of the properties and applications of most widely used materials for packaging.

\begin{tabular}{|c|c|c|c|c|c|c|c|c|}
\hline \multirow{2}{*}{\multicolumn{2}{|c|}{ Packaging Material }} & \multicolumn{3}{|c|}{ Barrier } & \multirow{2}{*}{$\begin{array}{c}\text { Heat } \\
\text { Seal-Ability }\end{array}$} & \multirow{2}{*}{$\begin{array}{l}\text { Mechanical, Physical and } \\
\text { Chemical Properties }\end{array}$} & \multirow{2}{*}{ Application } & \multirow{2}{*}{ Reference } \\
\hline & & Oxygen & Moisture & Light & & & & \\
\hline \multirow{5}{*}{ Plastic } & $\begin{array}{l}\text { Low-density } \\
\text { polyethylene } \\
\text { (LDPE) }\end{array}$ & \multirow{3}{*}{ Very low } & High & \multirow{3}{*}{ Low } & \multirow{3}{*}{ Yes } & $\begin{array}{l}\text { Toughness, flexibility, } \\
\text { resistance to grease and } \\
\text { chemicals, temperature range } \\
-50-+80^{\circ} \mathrm{C}\end{array}$ & $\begin{array}{l}\text { Bags, flexible lids } \\
\text { and bottles }\end{array}$ & \multirow{4}{*}{ [12] } \\
\hline & $\begin{array}{l}\text { Linear } \\
\text { low-density } \\
\text { polyethylene } \\
\text { (LLDPE) }\end{array}$ & & High & & & $\begin{array}{l}\text { Toughness, extensibility, } \\
\text { resistant to grease, temperature } \\
\text { range }-30-+100^{\circ} \mathrm{C}\end{array}$ & (Strech) wrap & \\
\hline & $\begin{array}{l}\text { High-density } \\
\text { polyethylene } \\
\text { (HDPE) }\end{array}$ & & $\begin{array}{l}\text { Extremely } \\
\text { high }\end{array}$ & & & $\begin{array}{l}\text { Toughness, stiffness, resistance } \\
\text { to grease and chemicals, easy } \\
\text { processing and forming, } \\
\text { temperature range } \\
-40-+120^{\circ} \mathrm{C}\end{array}$ & $\begin{array}{l}\text { Bottles, cardboard } \\
\text { liners, tubs, bags }\end{array}$ & \\
\hline & $\begin{array}{l}\text { Polypropylene } \\
\text { (PP) }\end{array}$ & Low & High & Low & Yes & $\begin{array}{l}\text { Moderate stiffness, strong, } \\
\text { resistant to grease and } \\
\text { chemicals, temperature range } \\
\quad-40-+120^{\circ} \mathrm{C}\end{array}$ & $\begin{array}{l}\text { Bottles, cardboard } \\
\text { liners, tubs, } \\
\text { microwavable } \\
\text { packaging, bags }\end{array}$ & \\
\hline & $\begin{array}{l}\text { Polyethylene } \\
\text { terephthalate } \\
\text { (PET) }\end{array}$ & Good & Good & Low & Yes & $\begin{array}{l}\text { Stiffness, strong, resistance to } \\
\text { grease and oil, temperature } \\
\text { range }-60-+200{ }^{\circ} \mathrm{C}\end{array}$ & $\begin{array}{l}\text { Bottles, jars, tubs, } \\
\text { trays, blisters, films } \\
\text { (bags and } \\
\text { wrappers) }\end{array}$ & {$[12,40]$} \\
\hline \multirow{3}{*}{ Glass } & Transparent & \multirow{3}{*}{\multicolumn{2}{|c|}{ Absolute }} & Low & \multirow{3}{*}{\multicolumn{2}{|c|}{$\begin{array}{l}\text { High temperature and } \\
\text { pressure stability, brittle, } \\
\text { chemical resistance, } \\
\text { microwave-able }\end{array}$}} & \multirow{3}{*}{ Bottles, jars } & \multirow{3}{*}[12,40-42]{} \\
\hline & Green & & & Good & & & & \\
\hline & Brown & & & High & & & & \\
\hline \multicolumn{2}{|c|}{$\begin{array}{c}\text { Metal (aluminium, } \\
\text { tinplate, tin-free steel) }\end{array}$} & \multicolumn{3}{|c|}{ Absolute } & No & High temperature stability & $\begin{array}{l}\text { Bottles, cans, } \\
\text { tubs, caps }\end{array}$ & {$[12,40]$} \\
\hline \multicolumn{2}{|c|}{ Paper and board } & & $\begin{array}{l}\text { Extremely } \\
\quad \text { low }\end{array}$ & $\begin{array}{l}\text { High - extremely } \\
\text { high }\end{array}$ & No & Mechanical stability & Boxes, liners & {$[12,40,41]$} \\
\hline
\end{tabular}

The key properties of packaging materials of interest are physical and mechanical strength, barrier, migration, as well as hygiene. Regarding the physical and mechanical strength, it can be noted that static as well as dynamic stress challenges the packages along the supply chain from packing, storage, and transport to consumer use. Examples for static stress are stacking and increased pressure (vacuum or modified atmosphere packaging-MAP), as well as pointed or angular products. Dynamic stress on the other 
hand may be caused by the production process (e.g., printing, forming, filling) or transport (e.g., vibration). The right selection of the material, but also the shape of the packaging, therefore plays a vital role in the success of a primary, secondary or tertiary package (see also Figure 2) [12,13,38,43].

\section{Primary packaging}
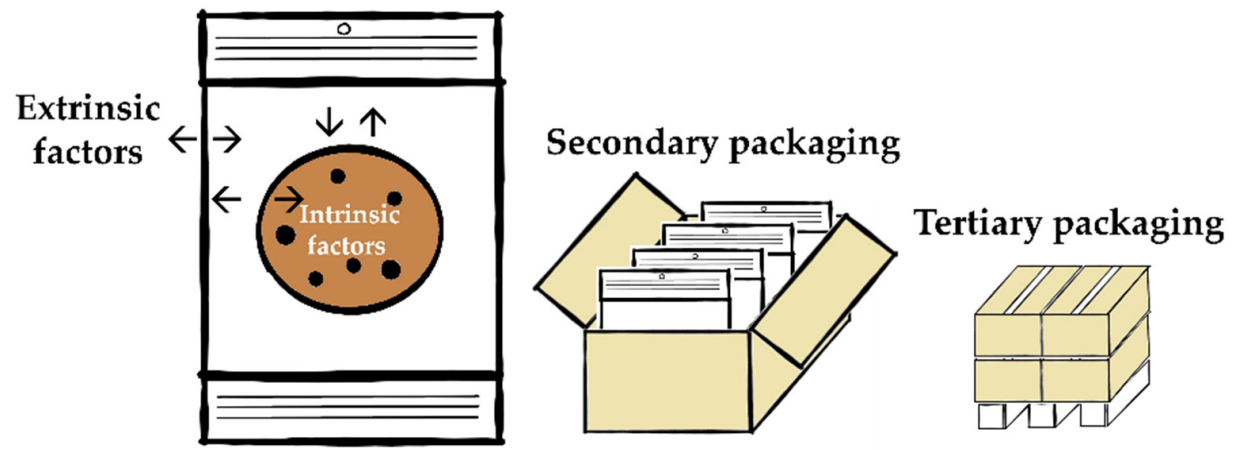

Figure 2. Schematic packaging levels of fine bakery ware (example: chocolate chip cookie), adapted from $[12,13,31]$.

Another key characteristic of materials to be considered is the barrier property. Especially, the barriers against oxygen $\left(\mathrm{O}_{2}\right)$ and water vapour $\left(\mathrm{H}_{2} \mathrm{O}\right)$ transmission are determinant since these can exhibit significant influences on product quality and safety. The former for example can promote oxidation reactions, loss of quality-determining ingredients (e.g., vitamins), and growth of spoilage and pathogenic microorganisms. The latter can influence structural changes such as hardening, agglomeration, or softening of products and promote microbial growth (see Section 3.2). Additionally, barriers against carbon dioxide $\left(\mathrm{CO}_{2}\right)$ and nitrogen $\left(\mathrm{N}_{2}\right)$, which are the often-used gases in MAP, as well as aroma components, are decisive. Depending on the use case and product requirement, material with an appropriate barrier, i.e., permeation characteristics, should be chosen. Complementary to the above described, the barrier against other substances like fat may be considered [12,13,38,44]. Furthermore, electromagnetic radiation (light) has to be taken into consideration, since oxidative or other chemical reactions as well as structural changes may be induced or accelerated, thus impairing product quality [12,41,45-47].

What is important regarding chemical safety is the migration of compounds from packaging materials into the food. Migration describes the mass transfer of substances from a packaging material into the food product or vice versa. As for the permeation, the driving force behind this phenomenon is the concentration gradient. Additionally, factors such as material, storage temperature, relative humidity, and time play an influencing role $[38,39,48]$.

Against common perception, possible migration of, for example, additives, are not only present in plastic packaging materials. Migration can also be found in other (primary or secondary (recycled)) materials such as glass (e.g., silicates), metal (e.g., corrosion of the metal, additive migration from organic coatings), paper and board (e.g., fillers, contaminations like mineral oils) and may, next to the packaging material itself, find its origin in packaging aids (e.g., labels, closures, coatings) or even set-off processes (e.g., printed and role-to-role processed or stapled materials) [12,13,38]. To ensure safety of food contact materials (including packaging), several legal requirements are in place in the European Union and beyond [39,48-53]. It should be noted that in addition to the migration from the packaging material to the food, migration processes from the food to the packaging can also be observed. This process is also called sorption or scalping and may cause alteration of the product (e.g., flavour loss) as well as reduced reusability of packaging containers due to the re-release of previously migrated substances [12,13].

In addition to chemical safety, packaging materials also play a role in the hygiene and biological safety of food products. Depending on the material used, a barrier against 
contamination, microorganisms and animals (e.g., food pests) can be given. To achieve a high standard of hygiene, it is crucial to utilize materials that pose a sufficient barrier and that are free from contamination. Further, it is important to use materials that do not support microbial growth. Lastly, it is important to recognise, that most packaging materials carry a low microbial count when freshly produced due to often high process temperatures (e.g., melting of glass). So, the microbial burden is often a result of recontamination during finishing processes, storage, and application, which can sometimes make it necessary to implement decontamination measures prior to the filling process [38,54].

\section{Cereal and Confectionary Products}

Against the above-summarized background, food packaging can be seen as a mediator between product and the environment, capable of significantly influencing food quality, safety, and shelf-life [12]. Regarding cereal and confectionary products, the following text aims at summarizing and categorizing the product group, presenting an overview of category specific decay mechanisms, as well as respective packaging solutions.

\subsection{Categorization of Cereal and Confectionary Products}

As shown by Belitz et al. [28], cereal and confectionary products cover a wide and diverse range of food products. They summarized different products in two groups, namely cereals and cereal products. The first group is mainly made from important staple foods such as wheat, rye, rice, barley, millet, oats and corn. These are used to produce different kinds of products. For example, Smith et al. [55] made the following division: “... unsweetened goods (bread, rolls, buns, crumpets, muffins and bagels), sweet goods (pancakes, doughnuts, waffles and cookies) and filled goods (fruit and meat pies, sausage rolls, pastries, sandwiches, cream cakes, pizza and quiche)".

The group of confectionery products are mainly sugar-based products that, in contrast to cereal products, are predominantly consumed as a "treat" rather than a full meal. These include products such as chocolate, hard candy, and pralines [56,57]. In addition to sweet confectionery, savory snacks can also be found on the market. According to Robertson [13], these include "... a very wide range of products, including potato and corn chips, alkali-cooked corn tortilla chips, pretzels, popcorn, extruded puffed and baked/fried products, half-products, meat snacks and rice-based snacks" [13,58]. In addition to that, there are combinations of sweet and savory snacks like chocolate covered pretzels or sweet popcorn [59].

In the available literature and other sources including statistics, codices and regulations, different approaches to properly (sub)categorize cereal and confectionary products can be found [59-61]. Taking a food and shelf-life perspective, it is reasonable to cluster products that exhibit similar characteristics or spoilage mechanisms. In the European Union, where there is a strong food law [62] in place, a comprehensive list can be, for example, found in the guidance document to Annex II of regulation (EC) No 1333/2008 on food additives $[59,63]$. For the field of cereals and confectionary, the four groups of confectionary, cereals and cereal products, bakery wares, and ready-to-eat savories and snacks are of special interest. While confectionary is further subdivided into cocoa and chocolate products, other confectionery products including breath freshening micro-sweets, chewing gum as well as decorations, coatings and fillings, cereals and cereal products are divided into whole, broken or flaked grain, flours, milled products and starches, breakfast cereals as well as pasta, noodles, batters and pre-cooked or processed cereals. For bakery wares, a classification into bread and rolls and fine bakery wares is given. Last but not least, savories and snacks are broken down into potato-, cereal-, flour- or starch-based snacks as well as processed nuts. For each of the above-mentioned subgroups, a comprehensive list of product examples is given in the mentioned document [59]. The present review adopts this categorization approach and structures relevant information on cereal and confectionary shelf-life, packaging, and shelf-life extension strategies accordingly (Figure 3). 

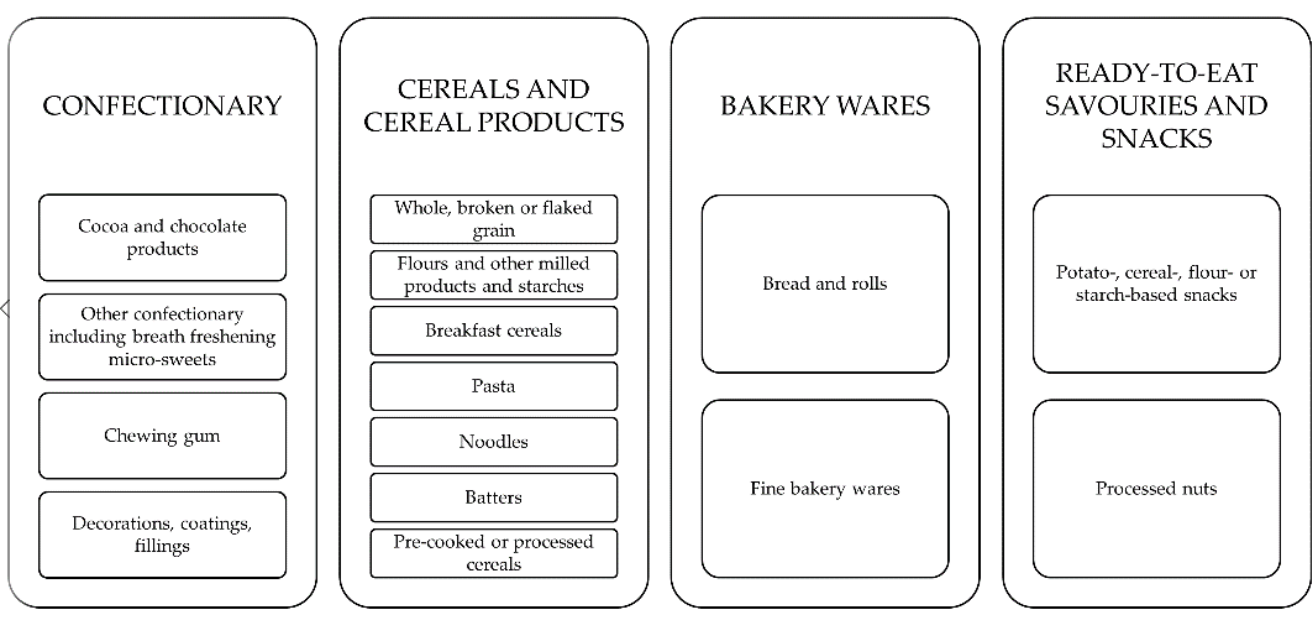

Figure 3. Representation of the followed product categorization. Adapted from [59].

\subsection{Decay Mechanisms and Shelf-Life}

It is well-established that intrinsic as well as extrinsic factors influence the quality of food and thus its shelf-life [13], which can be defined as the period of time a food maintains its safety and/or quality under reasonably foreseeable conditions of distribution, storage, and use [12,64-66]. Intrinsic factors include, amongst others, $\mathrm{pH}$, water activity $\left(\mathrm{a}_{\mathrm{w}}\right)$, initial microbial population, redox potential value (Eh), and nutrient content and therefore determine the nature of decay mechanisms of a food product. On the other hand, extrinsic factors determine how fast decay mechanisms proceed. Typical examples are atmosphere, climatic conditions, and illumination. Packaging itself acts as mediator or separator between intrinsic and extrinsic systems $[13,67]$. The following paragraphs highlight the main challenges of quality maintenance of cereal and confectionary products but do not go into detail about the physical, chemical, or biological bases of these mechanisms (e.g., oxidation). This information can be found in the relevant scientific literature $[13,67,68]$.

Focusing on cereal and confectionary products (see Table 2), moisture content (MC) and water activity $\left(\mathrm{a}_{\mathrm{w}}\right)$ are some of the most important quality-affecting parameters. Kong and Singh [69] define, that the $a_{w}$ value is "... the vapour pressure of water above a sample (p) divided by that of pure water at the same temperature (p0); i.e, $a_{w}=\frac{p}{p 0}$. It describes the degree to which water is free or bound to other components". They state that this is related to "...the composition, temperature, and physical state of the compounds" [69,70]. This is of importance regarding the potential growth of microorganisms as they depend on free water presence [71].

Table 2. Water activity and moisture content of confectionery products, breakfast cereals, snacks, and bakery products.

\begin{tabular}{|c|c|c|c|c|c|}
\hline Product category & Subcategory & Product & $\begin{array}{c}\text { Water Activity } \\
{\left[a_{w}\right]}\end{array}$ & $\begin{array}{c}\text { Moisture } \\
\text { Content [\%] }\end{array}$ & Reference \\
\hline \multirow{8}{*}{ Confectionery } & $\begin{array}{c}\text { Cocoa and } \\
\text { chocolate products }\end{array}$ & Chocolate & $0.42-0.60$ & 1.2 & {$[72]$} \\
\hline & \multirow{6}{*}{$\begin{array}{c}\text { Other confectionery } \\
\text { including breath freshening } \\
\text { micro-sweets }\end{array}$} & Hard candy & $0.25-0.40$ & $2.0-5.0$ & \multirow{2}{*}[73,74]{} \\
\hline & & Fudge, toffee & $0.45-0.60$ & $6.0-18.0$ & \\
\hline & & Nougat (white, dark) & 0.55 & $8.00-10.0$ & {$[13,75]$} \\
\hline & & Jelly, liquorice & $0.50-0.75$ & $8.0-22.0$ & \multirow{2}{*}[73,74]{} \\
\hline & & Marshmallow & $0.60-0.75$ & $12.0-22.0$ & \\
\hline & & Marzipan & $0.75-0.80$ & - & [13] \\
\hline & Chewing gum & Chewing gum & $0.40-0.65$ & $3.0-6.0$ & {$[73,74]$} \\
\hline
\end{tabular}


Table 2. Cont.

\begin{tabular}{|c|c|c|c|c|c|}
\hline Product category & Subcategory & Product & $\begin{array}{l}\text { Water Activity } \\
{\left[a_{\mathbf{w}}\right]}\end{array}$ & $\begin{array}{c}\text { Moisture } \\
\text { Content [\%] }\end{array}$ & Reference \\
\hline \multirow{5}{*}{$\begin{array}{l}\text { Cereals and cereal } \\
\text { products }\end{array}$} & $\begin{array}{l}\text { Whole, broken, } \\
\text { or flaked grain }\end{array}$ & Oats, grains, cereals & $0.34-0.70$ & $8.8-9.2$ & \multirow{5}{*}[13,72]{} \\
\hline & \multirow{2}{*}{ Breakfast cereals } & Cornflakes & $0.25-0.38$ & $1.7-3.5$ & \\
\hline & & Puffs & $0.17-0.20$ & $0.48-1.70$ & \\
\hline & Fresh pasta & Fresh pasta & $0.91-0.98$ & $\geq 24$ & \\
\hline & Dry pasta & Dry pasta & $0.33-0.57$ & $5.4-8.3$ & \\
\hline \multirow{11}{*}{ Bakery wares } & \multirow{6}{*}{ Fine bakery wares } & Sponge cake, muffins & $0.84-0.95$ & $21.0-40.0$ & \multirow{3}{*}[76,77]{} \\
\hline & & Croissant crust & $0.59-0.61$ & $8.0-10-0$ & \\
\hline & & Croissant crumb & $0.92-0.94$ & $30.0-33.0$ & \\
\hline & & Biscuits & $0.60-0.63$ & $1.5-3.0$ & {$[72,78]$} \\
\hline & & Wafers & $0.13-0.15$ & 2.1 & \multirow{2}{*}{ [72] } \\
\hline & & Cookies & $0.18-0.64$ & $1.4-11.7$ & \\
\hline & \multirow{5}{*}{ Bread and rolls } & Flat bread (no yeast) & - & $33.0-35.0$ & [79] \\
\hline & & $\begin{array}{l}\text { Sourdough bread, yeast } \\
\text { bread crumb }\end{array}$ & $0.91-0.95$ & $29.0-40.0$ & \multirow{8}{*}[72]{} \\
\hline & & $\begin{array}{l}\text { Sourdough bread, yeast } \\
\text { bread crust }\end{array}$ & $0.88-0.94$ & $26.0-32.0$ & \\
\hline & & Bagel crust & 0.96 & 38.5 & \\
\hline & & Bagel crumb & 0.92 & 31.0 & \\
\hline \multirow{4}{*}{$\begin{array}{l}\text { Ready-to-eat } \\
\text { savouries } \\
\text { and snacks }\end{array}$} & \multirow{3}{*}{$\begin{array}{l}\text { Potato-, cereal-, flour- or } \\
\text { starch-based snacks }\end{array}$} & Popcorn & 0.07 & 0.28 & \\
\hline & & Chips & $0.09-0.27$ & $0.3-1.3$ & \\
\hline & & $\begin{array}{l}\text { Crackers, grissini, } \\
\text { sticks, pretzels }\end{array}$ & $0.05-0.54$ & $1.1-5.4$ & \\
\hline & Processed nuts & Nuts, seeds, nibs & $0.15-0.75$ & $0.5-3.1$ & \\
\hline
\end{tabular}

With an $\mathrm{a}_{\mathrm{w}}$ lower than 0.75 , a large proportion of the products listed in Table 2 falls into the group of low-moisture or dried foods that additionally exhibit low (e.g., cornflakes) or high (e.g., crisps) fat content. In this group, water uptake and thus loss of, e.g., crispness, which occurs, e.g., in potato chips and breakfast cereals after gaining moisture at a range of 0.35 to $0.5 \mathrm{a}_{\mathrm{w}}$, is the main decay mechanism $[12,13,69,80]$. Other mechanisms include loss of aroma (e.g., flavoured products) or aroma uptake from the products' surrounding due to the often porous structure of the food products. Further, structural changes such as loss of integrity due to e.g., mechanical damage (e.g., breakage), softening, or caking may occur. While microbial growth is the basis for both, low and high fat types, oxidative mechanisms, which may lead to off-odours and -tastes and subsequently to quality loss in terms of overall acceptance, are often linked to the fat content and thus tend to increase with the same [12]. Examples that can be named are nuts, chips, biscuits, and cookies. All in all, this product group can, however, be described as rather stable and therefore storage under dry and ambient conditions is recommended and possible. For example, breakfast cereals and dry pasta stay stable under temperate conditions for 6-18 months and 48 months, respectively [72,81]. Confectionary products like pulled sugar are stable for 6-9 months under temperate conditions (e.g., $\sim 20^{\circ} \mathrm{C}$ ) [68].

Other products, including chocolate for example, can be allocated to compact foods with high fat content, a group mainly susceptible to the uptake of unwanted flavours and some (often minor) water exchange (uptake or loss) processes [12]. The latter can induce so-called blooming effects [13]. Sugar bloom on the one hand is often provoked by humid 
storage or rapid temperature changes and leads to the loss of surface gloss. Fat bloom on the other side is also known to cause quality related issues visible as a fine whitish layer [82]. Growth of microorganisms is, however, of minor importance in this product group. Storage under temperate or chilled conditions is therefore possible for up to 12-24 months [57].

Microbial growth is of major concern in the group of ready-to-eat and ready-tocook convenience food products (e.g., fresh pasta). At this point, in addition to spoilage microorganisms, pathogenic microorganisms play an essential role $[65,83]$. Further, water loss and structural changes can be named. Additionally, oxidation can significantly gain importance regarding shelf-life. Accordingly, chilled storage is often preferred $[13,67]$.

The area of bakery products can be divided into fresh bakery wares and ready-to-bake products. The first group (e.g., bread) shows high $\mathrm{a}_{\mathrm{w}}$ values $(>0.8)$ and thus short shelf-life, which is heavily influenced by water exchange processes that are often interlinked with structural changes (softening of the crust and drying of the crumb). Connected to this, starch retrogradation, which is the main mechanism of staling, can be highlighted [69]. Further, loss of moisture and hardening with $\mathrm{a}_{\mathrm{w}}$ values below $0.5-0.7[13,69,80]$ quickly result in low sensory acceptance of the products. While oxidation and rancidity play a minor role in this food category, uptake of flavours as well as microbial spoilage play a more elaborated role in this product group. The latter point is mainly driven by the often visible growth of moulds and yeasts on the food surface. Characteristic microorganisms are Penicillium roqueforti, Hansenula anomala, Pichia anomala, Candida guilliermondii, C. parapsilosis, Saccharomyces cerevisiae, S. exiguus, S. unisporus, S. bayanus, S. pastorianus. Additionally, Clostridium and Bacillus genera are known bacteria potentially affecting bakery wares (sporeforming), with e.g. Bacillus spp. causing "rope" or "ropy spoilage" (Bacillus amyloliquefaciens, Bacillus subtilis, Bacillus pumilus, Bacillus cereus) [71,84,85]. Oxidation and rancidity play a minor role in this product category. Accordingly, the average shelf-life of fresh bread and cake under ambient conditions is often less than one week [86]. In some cases, chilled or frozen storage is advisable. The group of ready-to-bake rolls show very similar decay mechanisms. However, due to the higher water content, drying and spoilage is even more pronounced. In the case of frozen products, these mechanisms are delayed. A special focus has to be laid on water exchange (freezer burn) and structural damage [87].

\subsection{Product Group Specific Packaging}

Responding to the above-mentioned predominant decay mechanisms of cereal and confectionary products, the following section aims at highlighting common packaging concepts and material choices (compare also Table 1).

Chocolate packaging has to provide a good barrier against aroma, gas (especially $\mathrm{O}_{2}$ and $\mathrm{H}_{2} \mathrm{O}$ ) as well as light. This is conventionally achieved by using aluminium foil of different thickness to wrap the product. Since aluminium alone cannot be heat sealed, the per se excellent barrier of the material is, however, interrupted at, e.g., overlapping areas or gaps. Hence, diffusion (mass transfer) of aroma, gas and other molecules (e.g., mineral oil components) to the product cannot be excluded. Additionally, the originality of the product, an important factor of food safety, may not be ensured [13,67]. For this and other reasons (e.g., communication), many described packaging concepts (still) include an additional packaging layer, namely paper or paperboard [13,27,88-92].

Today, more and more multilayer materials can be found on the market. For example, laminates of LDPE (low density polyethylene) and aluminium allow for heat sealing of the aluminium by at the same time keeping the superior barrier and dead-fold properties of aluminium. Further, multilayer materials including paper or other aluminium replacing barrier materials (e.g., polyvinylidene dichloride (PVdC)) are available. Possible buildups may include LDPE/aluminium/paper or LDPE/PVdC, respectively [13]. Nowadays, a shift towards packaging made (solely) from (oriented) PP, which exhibits, due to a stretching process, inter alia, improved mechanical and barrier properties, is notable [21,92]. Additionally, cold sealing, is more and more adopted, since it avoids exposing sensitive products, such as chocolate, to elevated temperatures during heat sealing. This alternative 
is made possible by applying cold-seal adhesives on the intended sealing areas of the packaging film and pressing of two of the sealing areas together [31].

Individually packed chocolate products, such as chocolate coated bars or pralines, are often bought for hedonistic reasons (e.g., treats, gift function) and thus the communication function (design) of these packages is frequently at the forefront $[13,56]$. While the functions of containment and protection are already met, these packages often use excess packaging materials and/or layers and for example consist of a (e.g., polyethylene terephthalate (PET)) tray with individual cavities, (e.g., aluminium) wrapping of the individual pieces, a (e.g., paperboard) box, (e.g., polyethylene (PE) or polypropylene (PP)) overwrapping and packaging aids (e.g., labels, stickers). Glass or metal is also used in some cases [13].

Many confections, such as hard candies, gums, toffees and caramels are likewise (twist) wrapped individually. This is either for technical reasons such as provision of an adequate $\left(\mathrm{H}_{2} \mathrm{O}\right)$ barrier and thus avoidance of moisture loss or uptake, resulting in e.g., drying or agglutination of the product pieces, hygienic reasons or distinction from other products. As for chocolate, tightness of the package should be in the ideal case assured [73]. Due to their in general good barrier properties and sealability, the market dominating polyolefins (PE and PP) as well as PET [93] are also frequently used in this product category (e.g., multipacks) [21,94]. If elevated barriers are needed, different multilayer materials are also adopted. Further, glass and metal packaging can be found on the market and traditional materials include waxed paper, waxed glassine and waterproof, plasticized cellulose fibre [57]. Plain paper and board are, however, hardly used as a primary packaging material, since products tend to stick to the material. The packaging types in this product category are manifold and include, for example, trays, flow packs, boxes (for example cardboard and metal) and jars [13].

Other products such as biscuits, (processed) nuts and fruits are traditionally packaged in regenerated cellulose (trade name Cellophane) fibres (RCF). Therefore, RCF is usually coated with either LDPE or PVdC copolymer and often with a layer of glassine in direct contact with the product if it contains fat. Currently, this combination of materials is replaced by PP, either as plain or pearlized OPP film, coextruded OPP (OPPcoex) film, or acrylic-coated (Ac) on both sides. Plain OPP films require a heat seal coating to improve sealability while coextruded OPP provides superior seal strength. If a high $\mathrm{O}_{2}$ barrier is required, then acrylic-coated OPP (AcOPP) is used. One side is sometimes coated with PVdC copolymer rather than Ac. In addition, Ac and PVdC copolymer-coated OPP films provide a superior flavour and aroma barrier compared with that of uncoated OPP. Biscuits are often packed in PP and additionally a cardboard box, acting as secondary packaging $[13,25]$.

In comparison to other products, the dry and low in fat group of cereals and cereal products, (such as whole, broken, flaked or milled) grains (e.g., wheat and rice) show rather low packaging demands. Mostly used are paper bags, flexible plastic bags (e.g., PE [95]), as well as cardboard boxes [96,97]. There are also variations of these packages, for example inner flexible plastic bag and a secondary cardboard box. If paper is used and high barriers are needed, LDPE liners for example can be applied [13], also to avoid mineral oil migration [98]. Rigid laminates with paper content and plastic lids usually known in snack product packaging, are also available. Flours for example are commercially packaged in bags or bulk bins [13]. In addition to that, woven PP bags are commonly used in developing countries. However, Forsido et al. [99] discussed that the low moisture barrier led to chemical, physical, sensorial, and microbial changes of flour. Another successful approach for flour packaging that was used for decades, was bags made from cotton twill [13].

The barrier requirements for breakfast cereals packaging are set higher than in the above-mentioned group since crispness, formation of off-flavours, loss of aroma and vitamins or breakage are more critical for consumer acceptance [13]. Consequently, the inner packaging/primary packaging level of these products is a plastic bag, mostly HDPE (high density polyethylene), giving a sufficient water vapour barrier since moisture vapour trans- 
mission rates less than or equal to $15 \mathrm{~g} / \mathrm{m}^{2}$-day-atm are often required. Sealant polymers such as EVA (ethylene vinyl acetate), ionomer, $\mathrm{mPE}$ (metallocene polyethylene), or blends are used for low temperature seals, form-fill-seal packaging, and easy opening seals [95]. In order to increase barrier characteristics, HDPE is also coextruded with a thin layer of EVA or PA (polyamide) and EVOH (ethylene vinyl alcohol) polymers [95,100]. Other $\mathrm{O}_{2}$ barrier materials for breakfast cereals are PVdC and coated polypropylene-low density polyethylene [101]. In addition, PP-bags are common liners. The secondary packaging/outer packaging is most frequently a fibreboard box $[13,22]$. Alternative packaging concepts include coated paperboard, plastic cups, as well as metal boxes and glass jars [13,102].

Dried pasta is often packaged in paperboard carton, containing a plastic window. At the moment, most pasta products are packaged in plastic films, such as PE or oriented polypropylene [13,103-107]. For fresh pasta/noodle products, packaging solutions might be different, as appropriate barriers (gas and/or water vapour) and/or MAP (e.g. $\mathrm{CO}_{2}: \mathrm{N}_{2}$ $20: 80 \%$ MAP for pasta) is needed $[107,108]$. The selection of packaging materials for fresh pasta products can also depend on whether or not the product is pasteurized (thus, the package must be able to withstand the pasteurization conditions) and whether or not the product is to be heated in its package (the package must be able to withstand either heating in boiling water or microwave conditions) by the consumer. For products which are not pasteurized nor intended to be heated in their package, a rigid tray of PVC-LDPE sealed with PA-LDPE film is common. When microwave heating is used, the rigid tray is usually made from crystalline polyethylene terephthalate (PET-C), or polystyrene-ethylene vinyl alcohol copolymer-LDPE (PS-EVOH-LDPE) laminate, and the film may be based on PVdC copolymer-coated PET, OPET-EVOH-LDPE, or PP [109].

Packaging of fresh bakery products such as bread is a moisture balancing act. On one hand, moisture needs to be contained to prevent drying of the product and on the other hand, moisture has to be released from the product to avoid softening of the crust and microbial spoilage. Since there is a wide range of products and product characteristics, also a wide range of packaging solutions can be found. Frequently, paper-based materials, LDPE, LLDPE, HDPE bags as well as OPP, either as plain, pearlized, OPPcoex, or Ac/OPP/Ac films are used [13,95,110-114]. The bags are usually closed either with a strip of adhesive tape or a (plastic) clip in order to reduce moisture loss [111,113,115]. EVA polymers are also used for sealability and optics [95]. Perforated LDPE bags are used (for crusty products) in order to prevent the formation of a leathery consistency of the crust due to moisture migration from the crumb [115]. If aroma and taste barriers are needed, PA is used [95]. Vacuum packaging including the use of respective barrier packaging materials is only used in some exceptions (e.g., flat breads) in this product category due to mechanical impairment of the often soft products. MAP rich in $\mathrm{CO}_{2}$ is whereas more frequently used (e.g., sliced bread, convenience applications). For example, $\mathrm{CO}_{2}: \mathrm{N}_{2}$ 60:40\% MAP for bread, cakes, crumpets, crepes, fruit pies and pita bread. This is also the case for ready-to-bake products, which are intended to have a longer shelf-life [13].

Packaging for fried snack foods such as potato or tortilla chips, which exhibit, due to their production process, low moisture and high fat contents, preliminarily aims at providing a barrier against gases $\left(\mathrm{H}_{2} \mathrm{O}\right.$ and $\left.\mathrm{O}_{2}\right)$ and light to avoid loss of crispness and increased oxidation/rancidity levels of the product [95]. Hence, these products are mainly packaged in high barrier multilayer films containing aluminium foil or metallisation (e.g., PET/Alu/LDPE; PETmet/LDPE; BOPP/BOPPmet) [31,94,116]. In addition, barrier polymers such EVOH or PVDC can be found in these materials. Further, rigid multilayer paper solutions with aluminium (for example spiral wound paper-board cans) or metal cans are also used. Since extruded and puffed snack foods exhibit lower fat levels and thus primarily rely on a package that provides a barrier against water vapour; these products are less often packaged in metallized materials. An example is OPP/LDPE/OPP [95]. In both scenarios, and whether flexible or rigid packaging is adopted, modified atmosphere packaging is frequently used. For example, the package is usually flushed with an inert gas $\left(\mathrm{N}_{2}\right)$ before closing [116]. Additional mechanical protection of the often fragile products 
and dry storage is recommended. This might lead to the use of secondary packaging, such as cardboard boxes [31].

\section{Shelf-Life Extension}

As can be seen from the above text, choosing the right packaging material concept can have a positive effect on quality maintenance and therefore shelf-life of cereal and confectionary products and food in general. Where particularly sensitive products (e.g., high $\mathrm{a}_{\mathrm{w}}$ value, high fat content or oxidation potential) are present (e.g., fresh pasta, fried snacks) or an elevated shelf-life has to be achieved (e.g., ready-to-bake rolls, fine bakery wares), modern packaging concepts such as modified atmospheric packaging or active (AP) and intelligent packaging (IP) are used (combined abbreviation: AIP). Manifold different approaches can be found regarding MAP, AP, and IP, each with different relevance for the discussed product subgroups, cereals and cereal products, confectionary, bakery wares and ready-to-eat savouries and snacks. However, for an impression of these, Figure 4 depicts selected examples.
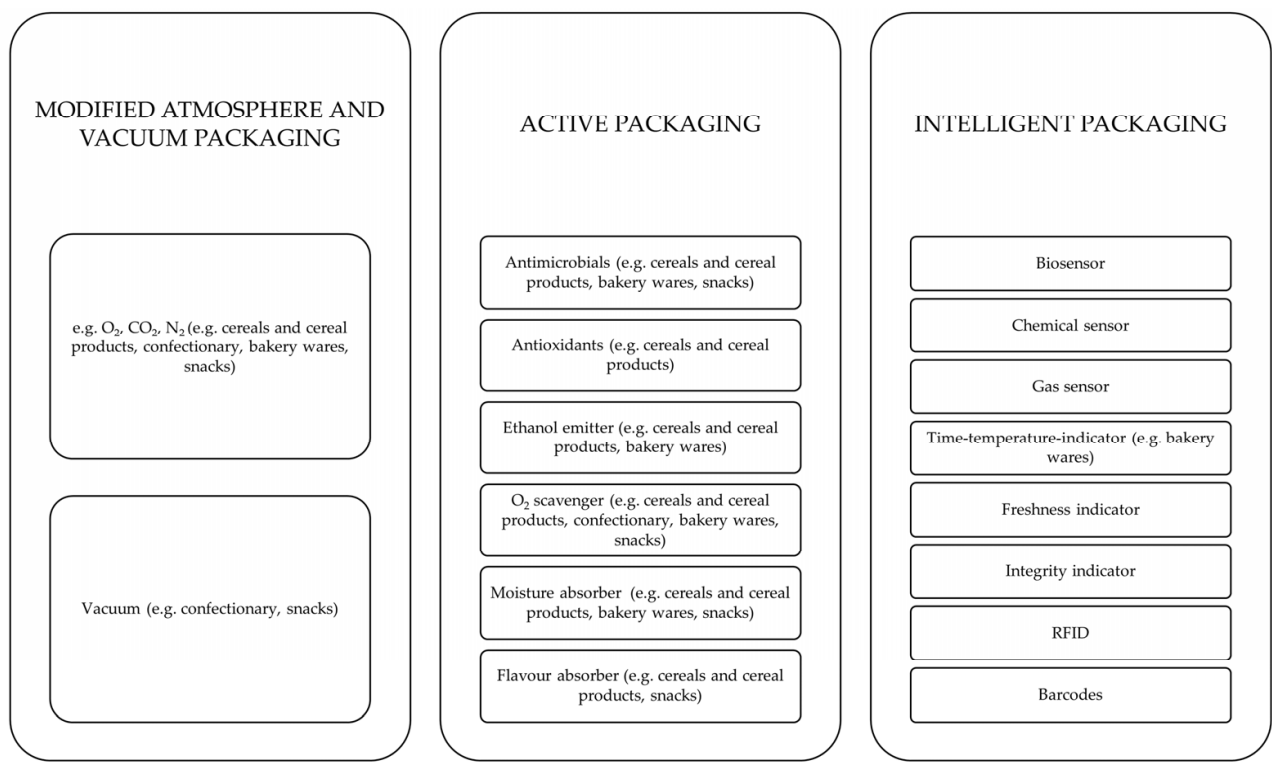

Figure 4. Selected examples of modified atmosphere, vacuum, as well as active and intelligent packaging approaches with certain use cases for cereal and confectionary packaging. Adapted from $[13,108,117-140]$.

Using these approaches, other product preservation actions (e.g., heating, use of preservatives) may be reduced, which supports attempts to reach a healthier diet (e.g., reduction of salt) or a clean label (e.g., avoidance of excess additives) [141] These allow specifically addressing other remaining challenges in the chemical, biological, mechanical, and physical fields $[12,13]$. Thus, they are also often implemented in the hurdle technology, a concept of combining diverse adverse factors or treatments to control microbial growth in food products $[13,142]$. According to studies found, also biobased and/or biodegradable packaging material is experimentally combined with AIP approaches. These materials offer new opportunities, for example in making use of different barrier properties, that allow a certain shelf-life extension $[134,135]$. Examples for MAP and AP with traditional as well as biobased/biodegradable packaging materials can be found in Table 3. 
Table 3. Effects of packaging material selection, active packaging (AP) and modified atmosphere packaging (MAP) on shelf-life extension of cereal and confectionary products. Abbreviations: $\mathrm{m}=$ month; $\mathrm{d}=$ day; $\mathrm{RH}=$ relative humidity; $\mathrm{RT}=$ room temperature .

\begin{tabular}{|c|c|c|c|c|c|c|}
\hline Category & Product & Packaging Material & AIP/MAP Applied & Storage & Shelf-Life & Reference \\
\hline \multirow{4}{*}{ Confectionary } & \multirow{4}{*}{$\begin{array}{l}\text { Dark chocolate } \\
\text { with hazelnuts }\end{array}$} & Alu (commercial) & Air & \multirow{4}{*}{$20^{\circ} \mathrm{C}$ in dark } & $8 \mathrm{~m}$ & \multirow{4}{*}{ [119] } \\
\hline & & PET/LDPE & \multirow{2}{*}{ Vacuum or $\mathrm{N}_{2}$} & & $8-9 \mathrm{~m}$ & \\
\hline & & PET-SiOx/LDPE & & & $11 \mathrm{~m}$ & \\
\hline & & PET/LDPE or PET-SiOx/LDPE & Oxygen absorber & & $\geq 12 \mathrm{~m}$ & \\
\hline \multirow{8}{*}{$\begin{array}{l}\text { Cereals and } \\
\text { cereal products }\end{array}$} & \multirow{2}{*}{$\begin{array}{l}\text { Muesli with chocolate } \\
\text { and apricots }\end{array}$} & Paper bag: PAP + PP window & \multirow[b]{2}{*}{ Air } & \multirow[b]{2}{*}{$20^{\circ} \mathrm{C}, \mathrm{RH} 55 \%$} & $2 \mathrm{~m}$ & \multirow[b]{2}{*}{ [143] } \\
\hline & & Pouch: PAP/Alu/PE & & & $9 \mathrm{~m}$ & \\
\hline & \multirow{2}{*}{ Fresh pasta } & PS tray + PVC film & Air & \multirow{2}{*}{$8^{\circ} \mathrm{C}$} & $20 \mathrm{~d}$ & \multirow{2}{*}{ [120] } \\
\hline & & PA/EVOH/LLDPE & $\mathrm{CO}_{2}: \mathrm{N}_{2} 22: 78 \% \mathrm{MAP}$ & & $40 \mathrm{~d}$ & \\
\hline & \multirow{2}{*}{$\begin{array}{l}\text { Fresh pasta filled } \\
\text { with cheese }\end{array}$} & \multirow{2}{*}{$\begin{array}{c}\text { Tray: EVOH/PS/PE wrapped in film: } \\
\text { EVOH/OPET/PE }\end{array}$} & Air & \multirow{2}{*}{$4^{\circ} \mathrm{C}$} & $7-14 \mathrm{~d}$ & \multirow{2}{*}{ [108] } \\
\hline & & & $\mathrm{CO}_{2}: \mathrm{N}_{2} 50: 50 \% \mathrm{MAP}$ & & $42 \mathrm{~d}$ & \\
\hline & \multirow{2}{*}{$\begin{array}{l}\text { Gluten-free fresh } \\
\text { filled pasta }\end{array}$} & Tray: PETFilm: antifog PET film & Air & \multirow{2}{*}{$4^{\circ} \mathrm{C}$} & $14 \mathrm{~d}$ & \multirow{2}{*}{ [121] } \\
\hline & & Tray: EVOH/PS/PEFilm: EVOH/OPET/PE & $\mathrm{CO}_{2}: \mathrm{N}_{2} 30: 70 \% \mathrm{MAP}$ & & $42 \mathrm{~d}$ & \\
\hline \multirow{11}{*}{ Bakery wares } & Sponge cake & PA/LLDPE & $\begin{array}{l}\text { Combinations of oxygen scavengers } \\
\text { with / without ethanol emitter }\end{array}$ & $30^{\circ} \mathrm{C}, \mathrm{RH} 60 \%$ & $\leq 42 \mathrm{~d}$ & [139] \\
\hline & \multirow{4}{*}{ Sliced wheat bread } & \multirow{4}{*}{ PET-SiOx/LDPE } & Bread & \multirow{4}{*}{$20^{\circ} \mathrm{C}$} & $4 \mathrm{~d}$ & \multirow{4}{*}{ [130] } \\
\hline & & & Bread + preservatives & & $6 \mathrm{~d}$ & \\
\hline & & & Ethanol emitter & & $24 \mathrm{~d}$ & \\
\hline & & & Ethanol emitter + oxygen absorber & & $30 \mathrm{~d}$ & \\
\hline & \multirow{6}{*}{ Ciabatta bread } & \multirow{6}{*}{$\mathrm{OPA} / \mathrm{PE}$} & Air (control) & & $5 \mathrm{~d}$ & \\
\hline & & & Air + ethanol spray & & $11 \mathrm{~d}$ & \\
\hline & & & $\mathrm{CO}_{2}: \mathrm{N}_{2} 10: 90 \% \mathrm{MAP}$ & $21^{\circ} \mathrm{C}$ & $12 \mathrm{~d}$ & [122] \\
\hline & & & MAP + ethanol spray & 21 & $13 \mathrm{~d}$ & $1+2-1$ \\
\hline & & & Air + ethanol emitter & & $25 \mathrm{~d}$ & \\
\hline & & & MAP + ethanol emitter & & $30 \mathrm{~d}$ & \\
\hline
\end{tabular}


Table 3. Cont.

\begin{tabular}{|c|c|c|c|c|c|c|}
\hline Category & Product & Packaging Material & AIP/MAP Applied & Storage & Shelf-Life & Reference \\
\hline & \multirow{3}{*}{ Wheat bread } & $\mathrm{HDPE} / \mathrm{PE}$ & - & \multirow{3}{*}{$\begin{array}{l}25.8^{\circ} \mathrm{C}, 275.5 \mathrm{~lx} \\
\quad \mathrm{RH} 31.2 \%\end{array}$} & $2 \mathrm{~d}$ & \multirow{3}{*}{ [144] } \\
\hline & & Unpackaged bread & - & & $3 \mathrm{~d}$ & \\
\hline & & HDPE/Nanoparticles/PE & $\mathrm{Ag}-\mathrm{TiO}_{2}$ & & $>6 \mathrm{~d}$ & \\
\hline & $\begin{array}{l}\text { Calcium-enriched } \\
\text { wholemeal bread }\end{array}$ & $\mathrm{PA} / \mathrm{PE}$ bag + cardboard box & $\mathrm{CO}_{2}: \mathrm{N}_{2} 60: 40 \% \mathrm{MAP}$ & $20^{\circ} \mathrm{C}$ & $24 \mathrm{~d}$ & [145] \\
\hline & Whole wheat bread & $\mathrm{PA} / \mathrm{PE}$ & $\mathrm{N}_{2}$ & RT & $2-3 w$ & [123] \\
\hline & \multirow{2}{*}{$\begin{array}{l}\text { Part-baked flat bread } \\
\text { (Sangak) }\end{array}$} & \multirow{2}{*}{$\mathrm{PA} / \mathrm{PE}$} & Air & \multirow{2}{*}{$25^{\circ} \mathrm{C}$} & $9 \mathrm{~d}$ & \multirow{2}{*}{ [124] } \\
\hline & & & $\mathrm{CO}_{2} 100 \% \mathrm{MAP}$ & & $21 \mathrm{~d}$ & \\
\hline & \multirow{3}{*}{ Sliced wheat bread } & \multirow{3}{*}{ Tray: APET/EVOH/PEAntifog-film: PA/PE } & $\begin{array}{l}\text { Air without potassium sorbate \& } \\
\text { with } 0.15 \% \text { potassium sorbate }\end{array}$ & \multirow{3}{*}{$20{ }^{\circ} \mathrm{C}, \mathrm{RH} 60 \%$} & $14 \mathrm{~d}$ & \multirow{3}{*}{ [125] } \\
\hline & & & $\begin{array}{c}\mathrm{N}_{2} 100 \% \text { MAP, } \mathrm{CO}_{2}: \mathrm{N}_{2} 30: 70 \% \mathrm{MAP} \\
\mathrm{CO}_{2}: \mathrm{N}_{2} \text { 50:50\% } \mathrm{MAP}, \mathrm{CO}_{2}: \mathrm{N}_{2} \\
70: 30 \% \text { MAP, } \mathrm{CO}_{2} 100 \% \mathrm{MAP} ; \text { with } \\
\text { \& without potassium sorbate }\end{array}$ & & $21 \mathrm{~d}$ & \\
\hline & & & Air with $0.30 \%$ potassium sorbate & & $>21 \mathrm{~d}$ & \\
\hline & Bread & Plastic bag & $\begin{array}{l}\text { E-Poly-L-Lysine Biofilms } 6.5 \mathrm{mg} \text { of } \\
\text { E-Poly-L-Lysine } / \mathrm{cm}^{2}\end{array}$ & $\begin{array}{l}\text { RT for } 7 \text { days } \\
\text { inoculated with } \\
\text { P. expansum }\end{array}$ & $+3 \mathrm{~d}$ & [131] \\
\hline & Sliced wheat bread & $\mathrm{PP} / \mathrm{PET} / \mathrm{LDPE}$ & Star anise oil, thymol & $\begin{array}{c}25^{\circ} \mathrm{C} \text { inoculated with } \\
\text { P. roqueforti }\end{array}$ & $14 \mathrm{~d}$ & [132] \\
\hline & Bread & Starch-based bionanocomposite film & Chitosan, grapefruit seed extract & $25^{\circ} \mathrm{C}, \mathrm{RH} 59 \%$ & $20 \mathrm{~d}$ & [133] \\
\hline & \multirow{3}{*}{ Sliced white pan bread } & PP bag & \multirow{2}{*}{-} & \multirow{3}{*}{$30^{\circ} \mathrm{C}$} & $2 d$ & \multirow{3}{*}{ [134] } \\
\hline & & PBAT-PLA bag & & & $3 \mathrm{u}$ & \\
\hline & & I DAP-1 LA Dag & Trans-cinnamaldehyde & & $\geq 21 \mathrm{~d}$ & \\
\hline & \multirow{3}{*}{ Bread } & BOPP & - & \multirow{3}{*}{$25^{\circ} \mathrm{C}, \mathrm{RH} 75 \%$} & $3 \mathrm{~d}$ & \multirow{3}{*}{ [135] } \\
\hline & & PLA & & & $6 \mathrm{~d}$ & \\
\hline & & PLA-PBSA bag & Thymol & & $7-9 \mathrm{~d}$ & \\
\hline
\end{tabular}




\subsection{Modified Atmosphere Packaging (MAP)}

Leaving quality sensitive products exposed to atmospheric conditions (gas composition of $\mathrm{N}_{2}, \mathrm{O}_{2}, \mathrm{Ar}, \mathrm{CO}_{2}$, traces of other gases) can trigger undesirable changes such as quality-related oxidative decay or growth of (non)pathogenic aerobic microorganisms. On the contrary, modifying the atmosphere inside a packaging can help maintain the quality of a product over an elevated timeframe. Consequently, common mitigation strategies include the reduction of packaging headspace and, thus, total available atmosphere or even removal of the atmosphere (to a value below one percent), which in turn results in vacuum packaging. To maintain these conditions over time, it is necessary to assure an appropriate containment function of the packaging by choosing packaging materials with an appropriate gas barrier and proper sealing. Challenges in this case are often the structure of the products and the corresponding residual oxygen in the packaging in the case of e.g., pores and the collapse of the product in the case of e.g., a soft structure $[13,125,146]$.

A more advanced modification can be found in a so-called modified atmosphere packaging, MAP [147]. Here, an active modification takes place in a two-step process, where first the initial atmosphere is removed (vacuum) and then replaced with a specific artificially composed atmosphere before closure of the barrier packaging. Commonly, in product-dependent concentrations used, colourless and odourless gases in MAP mainly encompass $\mathrm{CO}_{2}$ and $\mathrm{N}_{2}$. Due to its formation of hydrated carbonate species in aqueous phase $\mathrm{CO}_{2}$ is valued for its bacteriostatic and fungistatic effect, which increases with increasing concentration. Due to the solubility in water and fat, formation of under-pressure in the package and, consequently, possible collapse of the latter is possible. To avoid this and to act as a filler gas, the inexpensive and inert $\mathrm{N}_{2}$ is applied. Hence, passively, also this gas contributes to quality maintenance of the product. Furthermore, $\mathrm{O}_{2}$ is a frequently used gas but of little relevance for the cereal and confectionary sector. Its field of application is mostly in meat (e.g., bright-red colour preservation via high-oxygen MAP) and fish products and to lower extent in plant products $[145,148,149]$. More recently, permitted noble gases such as argon are subject to research but not broadly applied on cereal and confectionary products $[150,151]$. Depending on the chosen MAP gas composition, food shelf-life can increase manifold (50-400\%) and with this advantage along the supply chain can be recorded (e.g., less food waste, longer remaining shelf-life, less frequent production and transport). However, disadvantages linked to MAP, in general encompass the need for more sophisticated packaging materials and filling equipment, costs for gas and increased packaging volume [13].

Regarding the food categories at the centre of the present review, confectionary products are less frequently in the centre of research and application of MAP than cereals and cereal products, bakery wares or ready-to-eat savouries and snacks (see Table 3). One case of MAP use, however, is reported by Mexis et al. [119], for dark chocolate with hazelnuts. The authors found, that when conventionally used aluminium packaging together with storage under surrounding atmosphere was replaced with a PET/LDPE or PET-SiO $x$ packaging and vacuum or $\mathrm{N}_{2}$, the shelf-life (dark storage at $20^{\circ} \mathrm{C}$ ) was increased from 8 to $8-9$ and 11 months, respectively. Also Kita et al. [152], investigated the effects of different packaging types and shelf-life extension strategies for chocolate coated products (fruits and nuts). They analysed air, vacuum and MAP $\left(\mathrm{N}_{2} \geq 98 \%\right)$ of coated cherries, figs, hazelnuts and almonds in long term storage conditions in three different types of packaging. PP film closed with a clip was chosen for air, PP film sealed for vacuum and metallized sealed film for MAP. They resumed that the best packaging solutions for the chosen chocolate coated products, ensuring quality (for example bioactive compounds, antioxidative activity) were, on one hand, air and vacuum packaging for fruits, vacuum packaging for hazelnuts and MAP for almonds.

In the category of cereals and cereal products, and in more detail in fresh pasta, MAP often contains elevated amounts of $\mathrm{CO}_{2}$ (up to $80 \%$ ) and corresponding low $\mathrm{N}_{2}$ values (balance) $[13,108,120,121]$. For instance, Lee et al. [120] conducted a comparative study on fresh pasta packaged under air (PS tray with PVC film) and under $\mathrm{CO}_{2}: \mathrm{N}_{2} 78: 22 \% \mathrm{MAP}$ 
(PA/EVOH/LLDPE). As a result, the shelf-life was doubled from 20 to 40 days at a storage temperature of $8{ }^{\circ} \mathrm{C}$. Even higher rates of shelf-life increase for fresh filled pasta were shown in two other studies [108,121]. In the first case, samples included fresh pasta filled with cheese in a sealed tray (EVOH/PS/PE) with a barrier film (EVOH/OPET/PE) and two different atmospheres (air; $\mathrm{CO}_{2}: \mathrm{N}_{2}$ 50:50\% MAP). Quality maintenance was increased from 7-10 days up to 42 days [108]. Similarly, in the second case, gluten-free fresh pasta was packaged in trays (control: PET; test: EVOH/PS/PE) sealed with films (control: PET; test: EVOH/OPET/PE). Shelf life under air was compared to $\mathrm{CO}_{2}: \mathrm{N}_{2} 30: 70 \%$ MAP. Here, an increase from 14 to 42 days was notable [121].

Turning to bakery wares such as (pita)bread, cakes, crumpets, crepes, (fruit)pies, Robertson [13] reports a frequent use of $\mathrm{CO}_{2}: \mathrm{N}_{2}$ 60:40\% MAP. However, in the scientific literature, a more diverse application of $\mathrm{CO}_{2}: \mathrm{N}_{2} \mathrm{MAP}$ can be seen. For example, Rodriguez et al. [126] investigated extending the shelf-life of bread using MAP packaging in a combination with preservatives. The research referred to bread slices packaged in a $60 \mu \mathrm{m}$ bag. The results showed that in the samples without added preservative, and $\mathrm{CO}_{2}: \mathrm{N}_{2}$ 50:50\% MAP, the increases in shelf-life were $117 \%$ and $158 \%$ (at $22-25{ }^{\circ} \mathrm{C}$ and $15-20{ }^{\circ} \mathrm{C}$ ). For the samples with calcium propionate addition and in $\mathrm{N}_{2} 100 \% \mathrm{MAP}$, shelflife was increased by $116 \%$. Furthermore, calcium propionate addition and $\mathrm{CO}_{2}: \mathrm{N}_{2} 20: 80 \%$ MAP increased the shelf-life by $150 \%$ and $131 \%$ at $22-25^{\circ} \mathrm{C}$ and $15-20{ }^{\circ} \mathrm{C}$. When the $\mathrm{CO}_{2}$ concentration was increased to $50 \%$, the increased shelf-life of the samples with added preservative was $167 \%$ at $22-25^{\circ} \mathrm{C}$. For the same settings at $15-20{ }^{\circ} \mathrm{C}$ the increase was even $195 \%$. Fernandez et al. [149], conducted a similar research with soy bread. They as well used different settings of MAP and preservative adding but expanded the question of packaging options. They used two multilayer packaging solutions, high and medium barrier. The high barrier was LLDPE/PA/EVOH/PA/LLDPE, whereas the medium barrier solution was LLDPE/PA/LLDPE. As controls, LDPE and air atmospheres were used. The combination of high barrier packaging in $\mathrm{CO}_{2}: \mathrm{N}_{2} 50: 50 \%$ or $\mathrm{CO}_{2}: \mathrm{N}_{2} 20: 80 \%$ MAP without calcium propionate addition extended the shelf-life of the samples by at least $200 \%$.

Turning to ready-to-eat savouries and snacks (e.g., crisps) Sanches et al. [128] investigated inter alia the effects of different packaging atmospheres under $40{ }^{\circ} \mathrm{C}$ and room temperature on multiple crisp samples, linked to lipid oxidation. They included marketed products under unknown MAP concentrations, air, $\mathrm{N}_{2}$, vacuum and oxygen scavengers in the analysis. Reflecting changes in the fatty acid profile of the crisps, it was resumed that changes in the package's atmospheres, mostly cutting out oxygen, was crucial for the shelflife of the crisps. Vacuum packaging options would also allow stable lipid profiles, however, they are not suitable for easily breakable crisps. Del Nobile [129] was similarly questioning the optimal packaging for crisps, however, focused on finding the best headspace gas composition for two different multilayer film packages (metallized PP and PVdC coated $\mathrm{PE}$ ) through simulated storage. He proposed that $\mathrm{N}_{2}$ combined with water vapour would lead to a shelf-life extension up to $80 \%$.

\subsection{Active and Intelligtent Packaging (AIP)}

While MAP is firmly established in the market, active and intelligent packaging has not yet reached its full potential in food packaging applications but is at the threshold of more widespread use in the European market and subject to intense research and development activities [153-155]. Accordingly, the following paragraphs aim at outlining the concept of AIP and highlighting applications most relevant for cereal and confectionary packaging.

Just as conventional packaging applications, AIP define as food contact materials as given in Regulation (EC) No 1935/2004. While conventional packaging has to be sufficiently inert not to transfer substances to the food in quantities that endanger human health or bring an unacceptable change of the food product (composition, organoleptic properties), AIP are intentionally designed not to be inert. This allows them to actively maintain or even improve the quality or shelf-life of food products [39]. Hence, AIP deliberately includes "active" components that are either aimed to be released to the food or that aim at absorbing 
substances from it. This justifies the division of active packaging into so-called releaser and absorber systems. However, a clear distinction is made to traditional substance releasing materials (e.g., wooden barrels) in food contact. The use of active substances aimed to be released to the food must also comply with the Directive 1333/2008 on food additives and should be authorized accordingly by applicable community provisions [63]. Furthermore, specific requirements regarding labelling and information, avoidance of misleading consumers as well as safety assessment and authorisation is given [39]. In addition to Regulation (EC) No 1935/2004, Commission Regulation (EC) No 450/2009 gives specific rules for the use of AIP (e.g., community list of allowed substances for use and evaluation of these) $[39,156]$.

In response to major challenges in food quality and safety [12,13], key technologies in the area of active packaging are emitters (e.g., $\mathrm{CO}_{2}$, ethanol, antimicrobials, antioxidants) and scavengers (e.g., $\mathrm{O}_{2}, \mathrm{CO}_{2}$, ethylene), absorbers (e.g., $\mathrm{H}_{2} \mathrm{O}$, flavour and odour), self-venting packages, microwave susceptors, and temperature control packaging $[13,40,157-165]$. Intelligent packaging on the other hand refers to packaging that monitors the food product and provides information about its condition [39]. Related key technologies are mostly indicators and sensors (e.g., time, temperature) and linked processing and communication systems (e.g., (printed) electronics). Further, tamper evident packaging and anti-counterfeiting applications exist $[163,166]$.

Due to their effectiveness, the growth forecasts for AIP in the coming years are high, but it must be emphasised that the sustainability of such sophisticated packaging solutions should be evaluated case by case [167]. In addition to the actual reduction of food losses and food waste, factors such as, e.g., the recyclability of AIP, which may include metal-based components, should be evaluated [153,163,168,169].

Going into detail about cereal and confectionary packaging (see also Table 3), an application example for oxygen absorbers is in sliced bread. Where $\mathrm{O}_{2}$ concentration decreased below $0.1 \%$ within a few days of packaging, microbial shelf-life was shown to be extended. It was reported that there was no effect on sensory quality [170]. Oxygen absorber can also be used in combination with MAP. In 2003, Del Nobile et al. [127] showed that the application of $\mathrm{CO}_{2}: \mathrm{N}_{2}$ 80:20\% MAP in the packaging of durum wheat bread prolonged the shelf-life from 3 to about 18 days at $30^{\circ} \mathrm{C}$. However, if the packaging film itself possesses a high barrier against oxygen, neither the use of scavengers nor MAP are necessary to achieve the desired shelf-life of white bread [171]. Finally, an oxygen scavenger system, consisting of a multilayer coextruded bag associated with an oxygen scavenger, was tested in different storage conditions (accelerated storage, room temperature, refrigerator), for its effect on preservative-free tortillas shelf life. The results indicated a protective effect of the packages including the oxygen scavenger system. Specifically, the weight and thickness of flour tortillas under room temperature conditions could be maintained, opposed to respective decreases detected in control packages (consisting of LDPE/LLDPE). In parallel, yeast and mold growth were hold back in the packages containing the oxygen scavenger versus control (room temperature and accelerated storage). Under refrigerated conditions, a shelf-life up to 31 days was estimated, however, independed of the use of oxygen scavengers [172].

It has been also shown that the use of ethanol emitters extend shelf-life even without establishment of an additional modified atmosphere. For ciabatta, a shelf-life of 16 days, at $21{ }^{\circ} \mathrm{C}$ could be obtained, packaged in air atmosphere and ethanol emitter addition [122].

Antimicrobial, antifungal, and antioxidative agents as active food packaging include multiple research topics. Options include the applications of essential oils, edible films, and nanocomposites, which are often used with products susceptible to microbiological degradation, e.g., sliced bread. For example, oregano essential oil has been observed to be a successful application against yeasts and moulds in sliced bread. It was applied in the form of antimicrobial sachet at concentrations of 5, 10, and 15\% (v/w) at room temperature [136]. In addition to that, methylcellulose edible films produced with clove and oregano essential oil have displayed antimicrobial activity against spoilage fungi in bakery products and have improved sliced bread shelf-life to 15 days, at $25 \pm 2{ }^{\circ} \mathrm{C}$ [137]. 
Also, cinnamaldehyde was used as an active ingredient to increase the shelf-life of sliced bread. It was incorporated in gliadin films (5\%), which allowed to keep the quality of the product for 27 days of storage at $23{ }^{\circ} \mathrm{C}$ [173]. Next to having antimicrobial effects, essential oils are also antioxidative agents that can be included in packaging material like HDPE, LDPE, EVA. Zhu et al. [138] for example tested this approach with sesame essential oils for the packaging of oat cereals. However, there are also biological threats that could shorten the shelf-life of cereal and confectionery products. Essential oils from garlic, black pepper, ginger, fennel, and onion already have been tested as insect repellents for grain packaging. All these tested essential oils were characterized by significant fumigant insecticidal properties. For example, allyl mercaptan deriving from allium plants added as a sachet with rice flour, was proven as potential protective active packaging against $S$. oryzae contamination leaving sensory properties unaffected [174]. In general, the incorporation of essential oils in packaging materials is a growing sector $[175,176]$. One background can be that they are waterproof, so it could be the ideal material for the incorporation into a film, which will turn it from a conventional packaging material to an active one, increasing both its value and its functionality [175].

One further option of active packaging is the targeted use of composites at the nanoscale, whether organic (oils/proteins/carbohydrates) and/or inorganic, e.g., clays. This topic is of interest as active agents might have different properties in smaller scales. Materials of which at least one of its external dimensions belongs to the nanoscale (1 to $100 \mathrm{~nm}$ ) are considered nanomaterials $[177,178]$. They are characterized for their unique properties such us high surface-area-to-volume ratio, fine particle size, and high reactivity [179]. One common area of research interest is represented by publications including essential oils. For example, bio-nano-composite films prepared with corn starch incorporated with chitosan nano-clay, and further enriched with a variety of ratios of grapefruit seed extracts have been studied. It was shown that this solution was capable of inhibiting fungal proliferation for a period of 20 days, compared to that of 6 days in bread packaged samples with synthetic plastic, indicating a successful active packaging approach to extent the shelf-life of bakery products [133]. Furthermore, two different formulations mainly consisting of essential oils from several plants were evaluated for their potential antifungal properties in maize grains. Specifically, in a recent study, bioactive EVOH films including various essential oils have been characterized. Cinnamaldehyde, citral, linalool and isoeugenol were investigated to decrease the activity of $A$. steynii and $A$. tubingensis strains. It was shown that the ochratoxin A production by these strains in partly milled maize grains could be reduced significantly. The inhibitory effect was the highest in EVOH with cinnamaldehyde, followed by isoeugenol and citral [180]. In parallel, EVOH copolymer films incorporated with essential oils from Origanum vulgare, Cinnamomum zeylanicum and/or their major active constituents have been studied. The results showed that carvacrol and cinnamaldehyde were effective in decreasing Aspergillus flavus and A. parasiticus-induced aflatoxin production in maize, respectively. Overall, cinnamaldehyde showed the highest inhibitory effect, followed by combinations of EVOH with essential oils from Origanum vulgare, Cinnamomum zeylanicum and carvacrol [181].

Next to these highly discussed organic nanoparticles, inorganic particles like Ag (silver) and $\mathrm{TiO}_{2}$ (titan dioxide) have also been applied to packaging solutions, for example cereal products, due to their antimicrobial effects [182-185]. However, there is a concern on potential risk of nanoparticles migrating into food, although limited data showed that obtained values were within the limits set by the legislation [185-189]. It was shown that $\mathrm{Ag}-\mathrm{TiO}_{2}$ nanocomposite incorporated in HDPE considerably extended shelf-life and microbiological safety of bread in comparison with control sample stored in an open atmosphere or in HDPE bags [144]. Not only the characteristics of plastic packaging can be optimized by the inclusion of nanoparticles. The modification of paper with $\mathrm{Ag}$ $\mathrm{TiO}_{2}-\mathrm{SiO}_{2}$ (silicon dioxide) or $\mathrm{Ag} / \mathrm{N}-\mathrm{TiO}_{2}$ composites can improve the papers material characteristics. It was shown that such paper was capable to extend the shelf-life of bread 
by 2 days in comparison to the control, in both ambient $\left(18-20{ }^{\circ} \mathrm{C}\right)$ and refrigerated $\left(0-4{ }^{\circ} \mathrm{C}\right)$ conditions [190].

Research in optimizing packaging with nanostructures goes even further to high-tech materials. An example is a packaging material with a montmorillonite layer. It was shown that montmorillonite composite polyamide 6 nano-fibres placed over PP films, increased the shelf-life of bread by 2 days at room temperature, due to inhibition of microbial growth [191].

Intelligent packaging, on the other hand, is a special packaging technique aiming to monitor the quality of the packaged food and to predict or measure the safe shelflife better than a best before marking date [122,130,171,192-194]. It provides functions beneath the ones considered as conventional e.g., protection and containment and is used to monitor the condition and provide quality information of packed foods to the consumers [158]. Different indicators, such as time-temperature, microbial growth, product freshness, pack integrity etc., are used as intelligent packaging systems. High temperatures and/or temperature fluctuation are often correlated with food deterioration as result of detrimental biochemical reactions combined with microbial growth. Depending on the food sensitivity specific intelligent indicators can be applied to specific food products. The time-temperature indicator measures the change that imitates the targeted quality characteristics with the same behaviour under the same time-temperature exposure. The $\mathrm{pH}$ and enzymatic indicators can also give information about the quality of food [195]. Commercially available time-temperature indicators can be used to monitor quality changes of many perishable and semi-perishable foods. Among other products, these indicators have been applied to canned fruitcake for 10 days' storage at constant $\left(12,25\right.$ and $\left.37^{\circ} \mathrm{C}\right)$ temperatures. Sensory analysis, as quality characteristic of the product, was correlated with indicator response [140,196].

Reflecting the above chapters and findings, it can be summarized and confirmed that, if chosen correctly, cereal and confectionary packaging, as well as food packaging in general can make a valuable contribution to maintaining the quality and safety of food $[12,13,17]$. Accordingly, it can also help to prevent food losses and waste, an important point when it comes to making our food systems more sustainable [11,16]. This point is also taken up in the SDGs and influences current political efforts such as the European Union's Green Deal $[2,3,6]$.

However, packaging redesign or optimizations should not simply be carried out without evaluating the effects on ecological, social, and economic sustainability as objectively as possible. This is the only way to avoid possible hidden trade-offs [17].

In addition, close cooperation between a wide range of disciplines is required. In this context, and among others, material science, sustainability science and social sciences, and humanities can be mentioned in addition to food science and technology. The latter in particular has, however, an important enabling function $[197,198]$. The future focus here could be on the points of promoting (i) diverse and sustainable primary produce, (ii) new processes and systems for sustainable manufacture, (iii) reduction of food and material waste along the supply chain, (iv) safety and traceability, (v) affordable and balanced nutrition, (vi) healthy diets as well as (vii) digitalization. MAP and AIP are important approaches in this context, which are particularly present in the points (ii), (iii) and (iv) [198].

\section{Conclusions}

The ongoing discussion about packaging optimization towards the enhancement of the sustainability of certain products, asks for a profound review of the status quo in specific food groups. Cereal and confectionary were found to be underrepresented in recent publications addressing this topic, despite their global economic and ecologic importance. To take the right steps aspiring more sustainable production and consumption of goods, it is essential for practitioners along the food supply chain to thoroughly understand packaging functions (containment, protection, convenience, communication), properties 
(physical and mechanical strength, barrier, migration, hygiene), product group specific decay mechanisms, used packaging solutions, and shelf-life extension strategies.

Commonly available packaging solutions vary in material selection (glass, metal, plastic, paper), as well as in shape (rigid, semi-rigid, flexible) and size. Therefore, each packaging solution offers unique benefits and limitations regarding its optimization potential. Important decay mechanisms mediated by packaging in cereal and confectionary products and snacks include inter alia oxidative mechanisms and changes in moisture content. Especially for products for which quality is easily impaired through such mechanisms, packaging solutions and technologies extending the shelf-life need to be considered as ways to improve the products' sustainability. This, in combination with a proper material selection, includes the applications of MAP and AIP (e.g., scavengers, indicators, active ingredients) as well as novel approaches (e.g., nanotechnology).

However, sustainability improvement includes different other aspects. After the proper understanding of the packaging's purpose in these certain product categories and subcategories, the question of burden shares between the environmental impacts of the food product itself in comparison to its packaging must be considered along the whole life cycle. Thus, further research is deemed necessary to investigate data from related Life Cycle Assessment (LCA) studies and to combine the findings with the current status quo, in order to derive proper redesign steps for cereal and confectionary products. However, LCA is by default limited to environmental analysis and does not cover all sustainability dimensions. The inclusion of economic and social aspects would finally provide a holistic picture on how to attain more sustainable products.

Author Contributions: Conceptualization, V.K.; resources, A.-S.B., K.L., K.G., I.A., M.I.P., S.A., M.M., I.U.-U., T.V. and V.K.; writing-original draft preparation, A.-S.B., K.L., K.G., I.A., M.I.P., S.A., M.M., I.U.-U., T.V. and V.K.; writing-review and editing, A.-S.B., K.L., and V.K.; supervision, V.K.; project administration, V.K.; funding acquisition, V.K. All authors have read and agreed to the published version of the manuscript.

Funding: This article/publication is based upon work from COST Action Circul-a-bility, supported by COST (European Cooperation in Science and Technology). www.cost.eu (accessed on 17 February 2022).

Conflicts of Interest: The authors declare no conflict of interest.

\section{References}

1. United Nations Framework Convention on Climate Change. The Paris Agreement. 2016. Available online: https://unfccc.int/ sites/default/files/resource/parisagreement_publication.pdf (accessed on 2 February 2022).

2. United Nations. Transforming Our World: The 2030 Agenda for Sustainable Development. Resolution Adopted by the General Assembly on 25 September 2015. Available online: http://www.un.org/ga/search/view_doc.asp?symbol=A/RES/70/1\&Lang=E (accessed on 2 February 2022).

3. Communication from the Commission to the European Parliament, the European Council, the Council, the European Economic and Social Committee and the Committee of the Regions, Brussels, Belgium. 2019. Available online: https: / / eur-lex.europa.eu/ resource.html?uri=cellar:b828d165-1c22-11ea-8c1f-01aa75ed71a1.0002.02/DOC_1\&format=PDF (accessed on 2 February 2022).

4. European Commission. Annex to the Communication from the Commission to the European Parliament, the European Council, the Council, the European Economic and Social Committee and the Committee of the Regions: The European Green Deal, Brussels. Available online: https: / / eur-lex.europa.eu/resource.html?uri=cellar:b828d165-1c22-11ea-8c1f-01aa75ed71a1.0002. 02/DOC2\&format=PDF (accessed on 2 February 2022).

5. European Commission. Communication from the Commission to the European Parliament, the Council, the European Economic and Social Committee and the Committee of the Regions. A New Circular Economy Action Plan. For a Cleaner and More Competitive Europe. COM/2020/98 Final, European Commission Brussels, Belgium, 2020, 20. Available online: https://eur-lex.europa.eu/legalcontent/EN/TXT/ ?qid=1583933814386\&uri=COM:2020:98:FIN (accessed on 2 February 2022).

6. European Commission. Communication from the Commission to the European Parliament, the Council, the European Economic and Social Committee and the Committee of the Regions a Farm to Fork Strategy for a Fair, Healthy and Environmentally Friendly Food System. COM (2020) 381 Final. 2020. Available online: https:/ / eur-lex.europa.eu/legal-content/EN/TXT/?uri=CELEX: 52020 DC0381 (accessed on 2 February 2022). 
7. Food and Agriculture Organization of the United Nations. Global Food Losses and Food Waste: Extent, Causes and Prevention. Study Conducted for the International Congress SAVE FOOD! at Interpack2011 Düsseldorf, Germany, Rome. 2011. Available online: http:/ / www.fao.org/3/mb060e/mb060e.pdf (accessed on 2 February 2022).

8. FAO-Food and Agriculture Organization of the United Nations. The State of Food and Agriculture 2019. Moving forward on Food Loss and Waste Reduction; Licence: CC BY-NC-SA 3.0 IGO; FAO: Rome, Italy, 2019; Available online: https://www.fao.org/3/ca6 030en/ca6030en.pdf (accessed on 2 February 2022).

9. Crippa, M.; Solazzo, E.; Guizzardi, D.; Monforti-Ferrario, F.; Tubiello, F.N.; Leip, A. Food systems are responsible for a third of global anthropogenic GHG emissions. Nat. Food 2021, 2, 198-209. [CrossRef]

10. Hawkes, C.; Ruel, M. Value Chains for Nutrition: 2020 Conference Brief 4, Washington, DC, USA. 2011. Available online: https:/ /a4nh.cgiar.org/files/2013/06/ValueChainsForNutrition.pdf (accessed on 2 February 2022).

11. HLPE. Nutrition and Food Systems: A Report by the High-Level Panel of Experts on Food Security and Nutrition of the Committee on World Food Security, Rome. 2017. Available online: http:/ /www.fao.org/3/i7846e/i7846e.pdf (accessed on 2 February 2022).

12. Singh, P.; Wani, A.A.; Langowski, H.-C. (Eds.) Food Packaging Materials: Testing \& Quality Assurance; CRC Press Taylor \& Francis Group: Boca Raton, FL, USA, 2017; ISBN 9781466559943.

13. Robertson, G.L. Food Packaging: Principles and Practice, 3rd ed.; CRC Press: Boca Raton, FL, USA, 2013 ; ISBN 9781439862414.

14. European Commission. Communication from the Commission to the European Parliament, the Council, the European Economic and Social Committee and the Committee of the Regions: A European Strategy for Plastics in a Circular Economy, Brussels. 2018. Available online: https: / / eur-lex.europa.eu/resource.html?uri=cellar:2df5d1d2-fac7-11e7-b8f5-01aa75ed71a1.0001.02/DOC_ $1 \&$ format=PDF (accessed on 2 February 2022).

15. European Commission. ANNEXES to the Communication from the Commission to the European Parliament, the Council, the European Economic and Social Committee and the Committee of the Regions: A European Strategy for Plastics in a Circular Economy, Brussels. 2018. Available online: https:/ / eur-lex.europa.eu/resource.html?uri=cellar:2df5d1d2-fac7-11e7-b8f5-01aa7 5ed71a1.0001.02/DOC_2\&format=PDF (accessed on 2 February 2022).

16. HLPE. Food Losses and Waste in the Context of Sustainable Food Systems: A Report by the High-Level Panel of Experts on Food Security and Nutrition of the Committee on World Food Security, Rome. 2014. Available online: http://www.fao.org/3/i3901e/ i3901e.pdf (accessed on 2 February 2022).

17. Verghese, K.; Lewis, H.; Fitzpatrick, L. (Eds.) Packaging for Sustainability; Springer: London, UK, $2012 ;$ ISBN 9780857299871.

18. Clune, S.; Crossin, E.; Verghese, K. Systematic review of greenhouse gas emissions for different fresh food categories. J. Clean. Prod. 2017, 140, 766-783. [CrossRef]

19. Garnett, T. Where are the best opportunities for reducing greenhouse gas emissions in the food system (including the food chain). Food Policy 2011, 36, S23-S32. [CrossRef]

20. Poore, J.; Nemecek, T. Reducing food's environmental impacts through producers and consumers. Science 2018, 360, 987-992. [CrossRef]

21. Miah, J.; Griffiths, A.; McNeill, R.; Halvorson, S.; Schenker, U.; Espinoza-Orias, N.; Morse, S.; Yang, A.; Sadhukhan, J. Environmental management of confectionery products: Life cycle impacts and improvement strategies. J. Clean. Prod. 2018, 177, 732-751. [CrossRef]

22. Jeswani, H.K.; Burkinshaw, R.; Azapagic, A. Environmental sustainability issues in the food-energy-water nexus: Breakfast cereals and snacks. Sustain. Prod. Consum. 2015, 2, 17-28. [CrossRef]

23. Konstantas, A.; Jeswani, H.K.; Stamford, L.; Azapagic, A. Environmental impacts of chocolate production and consumption in the UK. Food Res. Int. 2018, 106, 1012-1025. [CrossRef]

24. Konstantas, A.; Stamford, L.; Azapagic, A. Evaluating the environmental sustainability of cakes. Sustain. Prod. Consum. 2019, 19, 169-180. [CrossRef]

25. Konstantas, A.; Stamford, L.; Azapagic, A. Evaluation of environmental sustainability of biscuits at the product and sectoral levels. J. Clean. Prod. 2019, 230, 1217-1228. [CrossRef]

26. Noya, L.I.; Vasilaki, V.; Stojceska, V.; González-García, S.; Kleynhans, C.; Tassou, S.; Moreira, M.T.; Katsou, E. An environmental evaluation of food supply chain using life cycle assessment: A case study on gluten free biscuit products. J. Clean. Prod. 2018, 170, 451-461. [CrossRef]

27. Recanati, F.; Marveggio, D.; Dotelli, G. From beans to bar: A life cycle assessment towards sustainable chocolate supply chain. Sci. Total Environ. 2018, 613-614, 1013-1023. [CrossRef] [PubMed]

28. Belitz, H.-D.; Grosch, W.; Schieberle, P. Cereals and Cereal Products. In Food Chemistry, 3rd ed.; Belitz, H.-D., Grosch, W., Schieberle, P., Eds.; Springer: Berlin/Heidelberg, Germany, 2004; pp. 673-746. ISBN 978-3-540-40818-5.

29. Statista. Retail Sales of Bread Sold in Europe from 2012 to 2021: (in Million U.S. Dollars). Available online: https: / www.statista. com/statistics/782120/bread-retail-sales-europe/ (accessed on 2 February 2022).

30. Caobisco. Facts and Figures: Key Data of the European Sector (EU27 + Switzerland and Norway). Available online: https: / / caobisco.eu/facts/ (accessed on 17 January 2022).

31. Soroka, W. Fundamentals of Packaging Technology, 5th ed.; Institute of Packaging Professional: Herndon, WV, USA, 2014; ISBN 0615709346. 
32. Kaßmann, M. Grundlagen der Verpackung: Leitfaden für die Fächerübergreifende Verpackungsausbildung; DIN Deutsches Institut für Normung: Berlin, Germany, 2014; ISBN 3410241922.

33. Wani, A.A.; Singh, P.; Langowski, H.-C. Food Technologies: Packaging. In Encyclopedia of Food Safety; Motarjemi, Y., Ed.; Elsevier Science: Burlington, UK, 2014; ISBN 978-0-12-378613-5.

34. Bauer, A.-S.; Tacker, M.; Uysal-Unalan, I.; Cruz, R.M.S.; Varzakas, T.; Krauter, V. Recyclability and Redesign Challenges in Multilayer Flexible Food Packaging-A Review. Foods 2021, 10, 2702. [CrossRef] [PubMed]

35. Dahlbo, H.; Poliakova, V.; Mylläri, V.; Sahimaa, O.; Anderson, R. Recycling potential of post-consumer plastic packaging waste in Finland. Waste Manag. 2018, 71, 52-61. [CrossRef] [PubMed]

36. Ceflex. Designing for a Circular Economy: Recyclability of Polylefin-Based Flexible Packaging. 2020. Available online: https: / / guidelines.ceflex.eu (accessed on 16 February 2021).

37. FH Campus Wien; Circular Analytics TK GmbH. Circular Packaging Design Guideline: Empfehlungen für Die Gestaltung Recyclinggerechter Verpackungen, Vienna. 2021. Available online: https:/ /www.fh-campuswien.ac.at/fileadmin/redakteure/Forschung/ FH-Campus-Wien_Circular-Packaging-Design-Guideline_V04_DE.pdf (accessed on 9 February 2022).

38. Bergmair, J.; Washüttl, M.; Wepner, B. Prüfpraxis für Kunststoffverpackungen: Lebensmittel-, Pharma- und Kosmetikverpackungen; Behr: Hamburg, Germany, 2012; ISBN 9783899479072.

39. Regulation (EC) No 1935/2004 of the European Parliament and of the Council of 27 October 2004 on Materials and Articles Intended to Come into Contact with Food and Repealing Directives 80/590/EEC and 89/109/EEC; European Parliament, Council of the European Union: Brussels, Belgium, 2004.

40. Han, J.H. (Ed.) Innovations in Food Packaging; Elsevier Ltd.: Amsterdam, The Netherlands, 2005; ISBN 978-0-12-311632-1.

41. Campbell-Platt, G. (Ed.) Food Science and Technology, 2nd ed.; John Wiley \& Sons, Ltd.: Hoboken, NJ, USA, 2017; ISBN 9780470673423.

42. Marsh, K.; Bugusu, B. Food Packaging? Roles, Materials, and Environmental Issues. J. Food Sci. 2007, 72, R39-R55. [CrossRef]

43. ISO 5801:2007 Industrial Fans Performance (Testing Using Standardized Airways). Available online: https://www.iso.org/obp/ ui/\#iso:std:iso:5801:ed-2:v1:en (accessed on 2 February 2022).

44. Detzel, A.; Bodrogi, F.; Kauertz, B.; Bick, C.; Welle, F.; Schmid, M.; Schmitz, K.; Müller, K.; Käb, H. Biobasierte Kunststoffe als Verpackung von Lebensmitteln; Bundesministerium für Ernährung und Landwirtschaft: Heidelberg, Germany, 2018; Available online: https:/ / www.ifeu.de/fileadmin/uploads/Endbericht-Bio-LVp_20180612.pdf (accessed on 27 September 2021).

45. Carlsson, D.J.; Wiles, D.M. Composites, Fabrication to Die Design. In Encyclopedia of Polymer Science and Engineering, 2nd ed.; Mark, H., Bikales, N.M., Overberger, C.G., Menges, G., Eds.; John Wiley \& Sons: New York, NY, USA, $1986 ;$ p. 665.

46. Fellows, P. Food Processing Technology: Principles and Practice, 3rd ed.; Woodhead Publishing Limited, CRC Press: Cambridge, UK, 2009; ISBN 1615830413.

47. Yam, K.L. (Ed.) The Wiley Encyclopedia of Packaging Technology, 3rd ed.; John Wiley \& Sons: Hoboken, NJ, USA, 2009; ISBN 0470087048.

48. Commission Regulation (EU) No 10/2011 of 14 January 2011 on Plastic Materials and Articles Intended to Come into Contact with Food Text with EEA Relevance; European Commission: Brussels, Belgium, 2011.

49. Commission Regulation (EC) No 2023/2006 of 22 December 2006 on Good Manufacturing Practice for Materials and Articles Intended to Come into Contact with Food (Text with EEA Relevance); European Commission: Brussels, Belgium, 2006.

50. BFR. Database BfR Recommendations on Food Contact Materials: Recommendations. Available online: https://bfr.ble.de/kse/ faces/DBEmpfehlung_en.jsp (accessed on 3 February 2022).

51. EDQM Council of Europe. Food Contact Materials and Articles. Available online: https://www.edqm.eu/en/food-contactmaterials-and-articles (accessed on 11 October 2021).

52. SR 817. 023.21-Verordnung des EDI vom 16. Dezember 2016 über Materialien und Gegenstände, die Dazu Bestimmt Sind, mit Lebensmitteln in Berührung zu Kommen (Bedarfsgegenständeverordnung): Bedarfsgegenständeverordnung; Eidgenössische Departement des Innern: Switzerland, 2016.

53. European Printing Ink Association EuPIA. EuPIA Guideline on Printing Inks Applied to Food Contact Materials. 2020. Available online: https:/ / www.eupia.org/fileadmin/Documents/Food_contact_material/2020-12-22_EuPIA_Guideline_on_Printing_ Inks_applied_to_Food_Contact_Materials.pdf (accessed on 3 February 2022).

54. Barone, C.; Bolzoni, L.; Caruso, G.; Salvatore, P. (Eds.) Food Packaging Hygiene; Springer: Berlin/Heidelberg, Germany, 2015; ISBN 9783319148267.

55. Smith, J.P.; Daifas, D.P.; El-Khoury, W.; Koukoutsis, J.; El-Khoury, A. Shelf Life and Safety Concerns of Bakery Products-A Review. Crit. Rev. Food Sci. Nutr. 2004, 44, 19-55. [CrossRef]

56. Wolf, B. Confectionery and Sugar-Based Foods. Reference Module in Food Science; Elsevier: Amsterdam, The Netherlands, 2016; ISBN 978-0-08-100596-5.

57. Subramaniam, P. The Stability and Shelf Life of Confectionery Products. In Stability and Shelf Life of Food, 2nd ed.; Subramaniam, P., Wareing, P., Eds.; Elsevier Science \& Technology: Cambridge, UK, 2016; ISBN 9780081004364.

58. Lusas, E.W.; Rooney, L.W. (Eds.) Snack Foods Processing; CRC Press LLC: Boca Raton, FL, USA, 2001; ISBN 1566769329.

59. European Commission. Guidance Document Describing the Food Categories in Part E of Annex II to Regulation (EC) No 1333/2008 on Food Additives. 2017. Available online: https://ec.europa.eu/food/system/files/2017-09/fs_food-improvement-agents_ guidance_1333-2008_annex-2.pdf (accessed on 4 February 2022). 
60. FAO. Cereal Supply and Demand Brief. Available online: http://www.fao.org/worldfoodsituation/csdb/en/ (accessed on 4 October 2021).

61. EUROSTAT. Prodcom Annual Data. 2020. Available online: https://ec.europa.eu/eurostat/web/prodcom/data/excel-filesnace-rev.2 (accessed on 4 October 2021).

62. Regulation (EC) No 178/2002 of the European Parliament and of the Council of 28 January 2002 Laying Down the General Principles and Requirements of Food Law, Establishing the European Food Safety Authority and Laying Down Procedures in Matters of Food Safety; EC: Brussels, Belgium, 2002.

63. Regulation (EC) No 1331/2008 of the European Parliament and of the Council of 16 December 2008 Establishing a Common Authorisation Procedure for Food Additives, Food Enzymes and Food Flavourings (Text with EEA Relevance); EC: Brussels, Belgium, 2008.

64. Regulation (EU) No 1169/2011 of the European Parliament and of the Council of 25 October 2011 on the Provision of Food Information to Consumers, Amending Regulations (EC) No 1924/2006 and (EC) No 1925/2006 of the European Parliament and of the Council, and Repealing Commission Directive 87/250/EEC, Council Directive 90/496/EEC, Commission Directive 1999/10/EC, Directive 2000/13/EC of the European Parliament and of the Council, Commission Directives 2002/67/EC and 2008/5/EC and Commission Regulation (EC) No 608/2004 Text with EEA relevance; EC: Brussels, Belgium, 2011.

65. Commission Regulation (EC) No 2073/2005 of 15 November 2005 on Microbiological Criteria for Foodstuffs (Text with EEA Relevance); EC: Brussels, Belgium, 2005.

66. Regulation (EC) No 852/2004 of the European Parliament and of the Council of 29 April 2004 on the Hygiene of Foodstuffs; EC: Brussels, Belgium, 2004.

67. Robertson, G.L. (Ed.) Food Packaging and Shelf Life: A Practical Guide; CRC Press: Boca Raton, FL, USA, 2009; ISBN 9781420078459.

68. Subramaniam, P.; Wareing, P. (Eds.) Stability and Shelf Life of Food, 2nd ed.; Elsevier Science \& Technology: Cambridge, UK, 2016; ISBN 9780081004364.

69. Kong, F.; Singh, R.P. Chemical Deterioration and Physical Instability of Foods and Beverages. In Stability and Shelf Life of Food, 2nd ed.; Subramaniam, P., Wareing, P., Eds.; Elsevier Science \& Technology: Cambridge, UK, 2016; pp. 43-76. ISBN 9780081004364.

70. Fabra, M.J.; Talens, P.; Moraga, G.; Martínez-Navarrete, N. Sorption isotherm and state diagram of grapefruit as a tool to improve product processing and stability. J. Food Eng. 2009, 93, 52-58. [CrossRef]

71. Lianou, A.; Panagou, E.Z.; Nychas, G.-J.E. Microbiological spoilage of foods and beverages. In The Stability and Shelf Life of Food, 2nd ed.; Subramaniam, P., Ed.; Woodhead Publishing: Cambridge, UK, 2016; pp. 3-42. [CrossRef]

72. Schmidt, S.J.; Fontana, A.J. Appendix E: Water Activity Values of Select Food Ingredients and Products. In Water Activity in Foods: Fundamentals and Applications; John Wiley \& Sons, Inc.: Hoboken, NJ, USA, 2007; pp. 407-420.

73. Ergun, R.; Lietha, R.; Hartel, R.W. Moisture and Shelf Life in Sugar Confections. Crit. Rev. Food Sci. Nutr. 2010, 50, 162-192. [CrossRef]

74. Bussiere, G.; Serpelloni, M. Confectionery and Water Activity Determination of AW by Calculation. In Properties of Water in Foods: In Relation to Quality and Stability; Simatos, D., Multon, J.L., Eds.; Springer: Dordrecht, The Netherlands, 1985; pp. 627-645. ISBN 978-94-010-8756-8.

75. Subramaniam, P.J. Shelf-Life Prediction and Testing. In Science and Technology of Enrobed and Filled Chocolate, Confectionery and Bakery Products; Talbot, G., Ed.; CRC Press: Boca Raton, FL, USA, 2009; pp. 233-254. ISBN 9781845693909.

76. Cauvain, S.P.; Young, L.S. Bakery Food Manufacture and Quality: Water Control and Effects, 2nd ed.; Wiley-Blackwell: Chichester, UK, 2008; ISBN 9781444301083.

77. Dury-Brun, C.; Jury, V.; Guillard, V.; Desobry, S.; Voilley, A.; Chalier, P. Water barrier properties of treated-papers and application to sponge cake storage. Food Res. Int. 2006, 39, 1002-1011. [CrossRef]

78. Davidson, I. Biscuit, Cookie and Cracker Production: Process, Production and Packaging Equipment, 2nd ed.; Academic Press, Elsevier: Amsterdam, The Netherlands, 2018; ISBN 0128155795.

79. Pekmez, H. Properties of Flour used in Flat Bread (Gaziantep pita) Production. Turk. J. Agric. Food Sci. Technol. 2019, 7, 209-213. [CrossRef]

80. Taoukis, P.; Labuza, T.; Sam Saguy, I. Kinetics of Food Deterioration and Shelf-Life Prediction. Handbook of Food Engineering Practice; CRC Press: New York, NY, USA, 1997.

81. Costa, A.L.C. Combination of Process Technology and Packaging Conditions to Improve the Shelf Life of Fresh Pasta. J. Food Process. Technol. 2014, 5. [CrossRef]

82. Machálková, L.; Hřivna, L.; Nedomová, Š.; Jůzl, M. The effect of storage temperature on the quality and formation of blooming defects in chocolate confectionery. Potravinarstvo Slovak J. Food Sci. 2015, 9. [CrossRef]

83. Jaroni, D.; Ravishankar, S.; Juneja, V. Microbiology of Ready-to-Eat Foods. In Ready-to-Eat Foods, 1st ed.; Hwang, A., Huang, L., Eds.; CRC Press: Boca Raton, FL, USA, 2010; pp. 1-60. [CrossRef]

84. Valerio, F.; de Bellis, P.; Di Biase, M.; Lonigro, S.L.; Giussani, B.; Visconti, A.; Lavermicocca, P.; Sisto, A. Diversity of spore-forming bacteria and identification of Bacillus amyloliquefaciens as a species frequently associated with the ropy spoilage of bread. Int. J. Food Microbiol. 2012, 156, 278-285. [CrossRef] [PubMed]

85. Pepe, O.; Blaiotta, G.; Moschetti, G.; Greco, T.; Villani, F. Rope-producing strains of Bacillus spp. from wheat bread and strategy for their control by lactic acid bacteria. Appl. Environ. Microbiol. 2003, 69, 2321-2329. [CrossRef] [PubMed]

86. Galić, K.; Gabrić, D.; Ćurić, D. Packaging and the Shelf Life of Bread; Reference Module in Food Science; Elsevier: Amsterdam, The Netherlands, 2019. 
87. Omedi, J.O.; Huang, W.; Zhang, B.; Li, Z.; Zheng, J. Advances in present-day frozen dough technology and its improver and novel biotech ingredients development trends-A review. Cereal. Chem. 2018, 96, 34-56. [CrossRef]

88. Neira, D.P. Energy sustainability of Ecuadorian cacao export and its contribution to climate change. A case study through product life cycle assessment. J. Clean. Prod. 2016, 112, 2560-2568. [CrossRef]

89. Büsser, S.; Jungbluth, N. LCA of Chocolate Packed in Aluminium Foil Based Packaging, Switzerland. 2009. Available online: http://www.alufoil.org/files/alufoil/sustainability/ESU_-_Chocolate_2009_-_Exec_Sum.pdf (accessed on 4 February 2022).

90. Boakye-Yiadom, K.; Duca, D.; Pedretti, E.F.; Ilari, A. Environmental Performance of Chocolate Produced in Ghana Using Life Cycle Assessment. Sustainability 2021, 13, 6155. [CrossRef]

91. Pérez-Neira, D.; Copena, D.; Armengot, L.; Simón, X. Transportation can cancel out the ecological advantages of producing organic cacao: The carbon footprint of the globalized agrifood system of ecuadorian chocolate. J. Environ. Manag. 2020, 276, 111306. [CrossRef] [PubMed]

92. Bianchi, F.R.; Moreschi, L.; Gallo, M.; Vesce, E.; Del Borghi, A. Environmental analysis along the supply chain of dark, milk and white chocolate: A life cycle comparison. Int. J. Life Cycle Assess. 2020, 26, 807-821. [CrossRef]

93. PlascticsEurope. Plasctics-The Facts. 2020. Available online: https://plasticseurope.org/knowledge-hub/plastics-the-facts-20 20/ (accessed on 19 January 2022).

94. Nilsson, K.; Sund, V.; Florén, B. Environmental Impact of the Consumption of Sweets, Crisps and Soft Drinks, Copenhagen. 2011. Available online: http:/ / www.diva-portal.org/smash/get/diva2:702819/FULLTEXT01.pdf (accessed on 17 February 2022).

95. Morris, B. Examples of Flexible Packaging Film Structures. The Science and Technology of Flexible Packaging; Elsevier: Amsterdam, The Netherlands, 2017; pp. 697-709. ISBN 9780323242738.

96. Kägi, T.; Wettstein, D.; Dinkel, F. Comparing rice products: Confidence intervals as a solution to avoid wrong conclusions in communicating carbon footprints. In Proceedings of the 7th International Conference on Life Cycle Assessment in the Agrifood Sector, Bari, Italy, 24 September 2010; pp. 229-233.

97. Nunes, F.A.; Seferin, M.; Maciel, V.G.; Flôres, S.H.; Ayub, M.A.Z. Life cycle greenhouse gas emissions from rice production systems in Brazil: A comparison between minimal tillage and organic farming. J. Clean. Prod. 2016, 139, 799-809. [CrossRef]

98. Urbelis, J.H.; Cooper, J.R. Migration of food contact substances into dry foods: A review. Food Addit. Contam. Part A 2021, 38, 1044-1073. [CrossRef]

99. Forsido, S.F.; Welelaw, E.; Belachew, T.; Hensel, O. Effects of storage temperature and packaging material on physico-chemical, microbial and sensory properties and shelf life of extruded composite baby food flour. Heliyon 2021, 7, e06821. [CrossRef] [PubMed]

100. Monahan, E.J. Packaging of ready-to-eat breakfast cereals. Cereal Foods World 1988, 33, 215-221.

101. Sakamaki, C.; Gray, J.I.; Harte, B.R. The influence of selected barriers and oxygen absorbers on the stability of oat cereal during storage. J. Packag. Technol. 1988, 2, 98-103.

102. Sieti, N.; Rivera, X.C.S.; Stamford, L.; Azapagic, A. Environmental impacts of baby food: Ready-made porridge products. J. Clean. Prod. 2018, 212, 1554-1567. [CrossRef]

103. Cimini, A.; Cibelli, M.; Moresi, M. Cradle-to-grave carbon footprint of dried organic pasta: Assessment and potential mitigation measures. J. Sci. Food Agric. 2019, 99, 5303-5318. [CrossRef]

104. Röös, E.; Sundberg, C.; Hansson, P.-A. Uncertainties in the carbon footprint of refined wheat products: A case study on Swedish pasta. Int. J. Life Cycle Assess. 2011, 16, 338-350. [CrossRef]

105. Saget, S.; Costa, M.P.; Barilli, E.; de Vasconcelos, M.W.; Santos, C.S.; Styles, D.; Williams, M. Substituting wheat with chickpea flour in pasta production delivers more nutrition at a lower environmental cost. Sustain. Prod. Consum. 2020, 24, 26-38. [CrossRef]

106. Nette, A.; Wolf, P.; Schlüter, O.; Meyer-Aurich, A. A Comparison of Carbon Footprint and Production Cost of Different Pasta Products Based on Whole Egg and Pea Flour. Foods 2016, 5, 17. [CrossRef]

107. Park, C.; Szabo, R.; Jean, A. A Survey of Wet Pasta Packaged Under a C02:N2 (20:80) Mixture for Staphylococci and their Enterotoxins. Can. Inst. Food Sci. Technol. J. 1988, 21, 109-111. [CrossRef]

108. Sanguinetti, A.; Del Caro, A.; Mangia, N.; Secchi, N.; Catzeddu, P.; Piga, A. Quality Changes of Fresh Filled Pasta During Storage: Influence of Modified Atmosphere Packaging on Microbial Growth and Sensory Properties. Food Sci. Technol. Int. 2011, 17, 23-29. [CrossRef]

109. Rachtanapun, P.; Tangnonthaphat, T. Effects of packaging types and storage temperatures on the shelf life of fresh rice noodles under vacuum conditions. Chiang Mai J. Sci. 2011, 38, 579-589.

110. Espinoza-Orias, N.; Stichnothe, H.; Azapagic, A. The carbon footprint of bread. Int. J. Life Cycle Assess. 2011, 16, 351-365. [CrossRef]

111. Jensen, J.K.; Arlbjørn, J.S. Product carbon footprint of rye bread. J. Clean. Prod. 2014, 82, 45-57. [CrossRef]

112. Svanes, E.; Oestergaard, S.; Hanssen, O.J. Effects of Packaging and Food Waste Prevention by Consumers on the Environmental Impact of Production and Consumption of Bread in Norway. Sustainability 2018, 11, 43. [CrossRef]

113. Williams, H.; Wikström, F. Environmental impact of packaging and food losses in a life cycle perspective: A comparative analysis of five food items. J. Clean. Prod. 2011, 19, 43-48. [CrossRef]

114. Korsaeth, A.; Jacobsen, A.Z.; Roer, A.-G.; Henriksen, T.M.; Sonesson, U.; Bonesmo, H.; Skjelvåg, A.O.; Strømman, A.H. Environmental life cycle assessment of cereal and bread production in Norway. Acta Agric. Scand. Sect. A Anim. Sci. 2012, 62, $242-253$. [CrossRef] 
115. Cauvain, S.P.; Young, L.S. Chemical and physical deterioration of bakery products. In Chemical Deterioration and Physical Instability of Food and Beverages; Skibsted, L., Risbo, J., Andersen, M., Eds.; Woodhead Publishing: Washington, DC, USA, 2010; pp. 381-412. ISBN 9781845699260.

116. Chinnadurai, K.; Sequeira, V. Packaging of Cereals, Snacks, and Confectionery. Reference Module in Food Science; Elsevier: Amsterdam, The Netherlands, 2016; ISBN 978-0-08-100596-5.

117. Qian, M.; Liu, D.; Zhang, X.; Yin, Z.; Ismail, B.B.; Ye, X.; Guo, M. A review of active packaging in bakery products: Applications and future trends. Trends Food Sci. Technol. 2021, 114, 459-471. [CrossRef]

118. Kuswandi, B. Active and intelligent packaging, safety, and quality controls. In Fresh-Cut Fruits and Vegetables: Technologies and Mechanisms for Safety Control; Siddiqui, M.W., Ed.; Elsevier Science \& Technology: San Diego, CA, USA, 2020; pp. 243-294. ISBN 9780128161845.

119. Mexis, S.; Badeka, A.; Riganakos, K.; Kontominas, M. Effect of active and modified atmosphere packaging on quality retention of dark chocolate with hazelnuts. Innov. Food Sci. Emerg. Technol. 2010, 11, 177-186. [CrossRef]

120. Lee, D.S.; Paik, H.D.; Im, G.H.; Yeo, I.H. Shelf life extension of Korean fresh pasta by modified atmosphere packaging. J. Food Sci. Nutr. 2001, 6, 240-243.

121. Sanguinetti, A.M.; Del Caro, A.; Scanu, A.; Fadda, C.; Milella, G.; Catzeddu, P.; Piga, A. Extending the shelf life of gluten-free fresh filled pasta by modified atmosphere packaging. LWT 2016, 71, 96-101. [CrossRef]

122. Hempel, A.W.; O’Sullivan, M.G.; Papkovsky, D.B.; Kerry, J.P. Use of smart packaging technologies for monitoring and extending the shelf-life quality of modified atmosphere packaged (MAP) bread: Application of intelligent oxygen sensors and active ethanol emitters. Eur. Food Res. Technol. 2013, 237, 117-124. [CrossRef]

123. Jensen, S.; Oestdal, H.; Clausen, M.R.; Andersen, M.L.; Skibsted, L.H. Oxidative stability of whole wheat bread during storage. LWT 2011, 44, 637-642. [CrossRef]

124. Khoshakhlagh, K.; Hamdami, N.; Shahedi, M.; Le-Bail, A. Quality and microbial characteristics of part-baked Sangak bread packaged in modified atmosphere during storage. J. Cereal Sci. 2014, 60, 42-47. [CrossRef]

125. Degirmencioglu, N.; Göcmen, D.; Inkaya, A.N.; Aydin, E.; Guldas, M.; Gonenc, S. Influence of modified atmosphere packaging and potassium sorbate on microbiological characteristics of sliced bread. J. Food Sci. Technol. 2010, 48, 236-241. [CrossRef] [PubMed]

126. Rodríguez, M.; Medina, L.M.; Jordano, R. Effect of modified atmosphere packaging on the shelf life of sliced wheat flour bread Food Nahr. 2000, 44, 247-252. [CrossRef]

127. Del Nobile, M.A.; Martoriello, T.; Cavella, S.; Giudici, P.; Masi, P. Shelf life extension of durum wheat bread. Ital. J. Food Sci. 2003, 15, 383-394.

128. Silva, A.S.; Hernández, J.L.; Losada, P.P. Modified atmosphere packaging and temperature effect on potato crisps oxidation during storage. Anal. Chim. Acta 2004, 524, 185-189. [CrossRef]

129. Del Nobile, M. Packaging design for potato chips. J. Food Eng. 2001, 47, 211-215. [CrossRef]

130. Latou, E.; Mexis, S.; Badeka, A.; Kontominas, M. Shelf life extension of sliced wheat bread using either an ethanol emitter or an ethanol emitter combined with an oxygen absorber as alternatives to chemical preservatives. J. Cereal Sci. 2010, 52, 457-465. [CrossRef]

131. Luz, C.; Calpe, J.; Saladino, F.; Luciano, F.B.; Fernandez-Franzón, M.; Mañes, J.; Meca, G. Antimicrobial packaging based on $\varepsilon$-polylysine bioactive film for the control of mycotoxigenic fungi in vitro and in bread. J. Food Process. Preserv. 2017, 42, e13370. [CrossRef]

132. Lee, J.; Park, M.A.; Yoon, C.S.; Na, J.H.; Han, J. Characterization and Preservation Performance of Multilayer Film with Insect Repellent and Antimicrobial Activities for Sliced Wheat Bread Packaging. J. Food Sci. 2019, 84, 3194-3203. [CrossRef] [PubMed]

133. Jha, P. Effect of grapefruit seed extract ratios on functional properties of corn starch-chitosan bionanocomposite films for active packaging. Int. J. Biol. Macromol. 2020, 163, 1546-1556. [CrossRef] [PubMed]

134. Srisa, A.; Harnkarnsujarit, N. Antifungal films from trans-cinnamaldehyde incorporated poly(lactic acid) and poly(butylene adipate-co-terephthalate) for bread packaging. Food Chem. 2020, 333, 127537. [CrossRef]

135. Suwanamornlert, P.; Kerddonfag, N.; Sane, A.; Chinsirikul, W.; Zhou, W.; Chonhenchob, V. Poly(lactic acid)/poly(butylenesuccinate-co-adipate) (PLA/PBSA) blend films containing thymol as alternative to synthetic preservatives for active packaging of bread. Food Packag. Shelf Life 2020, 25, 100515. [CrossRef]

136. Passarinho, A.T.P.; Dias, N.F.; Camilloto, G.P.; Cruz, R.S.; Otoni, C.; Moraes, A.R.F.; Soares, N.D.F.F. Sliced Bread Preservation through Oregano Essential Oil-Containing Sachet. J. Food Process Eng. 2014, 37, 53-62. [CrossRef]

137. Otoni, C.; Pontes, S.F.O.; Medeiros, E.A.A.; Soares, N.D.F.F. Edible Films from Methylcellulose and Nanoemulsions of Clove Bud (Syzygium aromaticum) and Oregano (Origanum vulgare) Essential Oils as Shelf Life Extenders for Sliced Bread. J. Agric. Food Chem. 2014, 62, 5214-5219. [CrossRef] [PubMed]

138. Zhu, X.; Schaich, K.; Chen, X.; Yam, K. Antioxidant Effects of Sesamol Released from Polymeric Films on Lipid Oxidation in Linoleic Acid and Oat Cereal. Packag. Technol. Sci. 2012, 26, 31-38. [CrossRef]

139. Janjarasskul, T.; Tananuwong, K.; Kongpensook, V.; Tantratian, S.; Kokpol, S. Shelf life extension of sponge cake by active packaging as an alternative to direct addition of chemical preservatives. LWT 2016, 72, 166-174. [CrossRef]

140. Wells, J.H.; Singh, R.P. Application of Time-Temperature Indicators in Monitoring Changes in Quality Attributes of Perishable and Semiperishable Foods. J. Food Sci. 1988, 53, 148-152. [CrossRef] 
141. Vargas, M.C.A.; Simsek, S. Clean Label in Bread. Foods 2021, 10, 2054. [CrossRef]

142. Leistner, L.; Gorris, L.G. Food preservation by hurdle technology. Trends Food Sci. Technol. 1995, 6, 41-46. [CrossRef]

143. Senhofa, S.; Straumite, E.; Sabovics, M.; Klava, D.; Galoburda, R.; Rakcejeva, T. The effect of packaging type on quality of cereal muesli during storage. Agron. Res. 2015, 13, 1064-1073.

144. Cozmuta, A.M.; Peter, A.; Cozmuta, L.M.; Nicula, C.; Crisan, L.; Baia, L.; Turila, A. Active Packaging System Based on $\mathrm{Ag} / \mathrm{TiO} 2 \mathrm{Nanocomposite}$ Used for Extending the Shelf Life of Bread. Chemical and Microbiological Investigations. Packag. Technol. Sci. 2014, 28, 271-284. [CrossRef]

145. Fik, M.; Surówka, K.; Maciejaszek, I.; Macura, M.; Michalczyk, M. Quality and shelf life of calcium-enriched wholemeal bread stored in a modified atmosphere. J. Cereal Sci. 2012, 56, 418-424. [CrossRef]

146. Smith, J.; Ooraikul, B.; Koersen, W.; Jackson, E.; Lawrence, R. Novel approach to oxygen control in modified atmosphere packaging of bakery products. Food Microbiol. 1986, 3, 315-320. [CrossRef]

147. Lee, D.S. Modified Atmosphere Packaging of Foods: Principles and Applications; John Wiley \& Sons Inc, Institute of Food Technologists: Hoboken, NJ, USA, 2021; ISBN 9781119530770.

148. Lucas, J. Integrating MAP with new germicidal techniques. In Novel Food Packaging Techniques; Ahvenainen, R., Ed.; CRC Press: Boca Raton, FL, USA, 2003; ISBN 128037294X.

149. Fernandez, U.; Vodovotz, Y.; Courtney, P.; Pascall, M.A. Extended Shelf Life of Soy Bread Using Modified Atmosphere Packaging. J. Food Prot. 2006, 69, 693-698. [CrossRef] [PubMed]

150. Heinrich, V.; Zunabovic, M.; Nehm, L.; Bergmair, J.; Kneifel, W. Influence of argon modified atmosphere packaging on the growth potential of strains of Listeria monocytogenes and Escherichia coli. Food Control 2016, 59, 513-523. [CrossRef]

151. European Parliament and Council Directive No 95/2/EC of 20 February 1995 on Food Additives Other than Colours and Sweeteners; EU Parliament: Brussels, Belgium, 1995.

152. Kita, A.; Lachowicz, S.; Filutowska, P. Effects of package type on the quality of fruits and nuts panned in chocolate during long-time storage. LWT 2020, 125, 109212. [CrossRef]

153. Tiekstra, S.; Dopico-Parada, A.; Koivula, H.; Lahti, J.; Buntinx, M. Holistic Approach to a Successful Market Implementation of Active and Intelligent Food Packaging. Foods 2021, 10, 465. [CrossRef]

154. Actinpak. Cost Action FP1405. Available online: http://www.actinpak.eu/ (accessed on 4 February 2022).

155. AIPIA. Active \& Intelligent Packaging Industry Association. Available online: https://www.aipia.info/ (accessed on 4 February 2022).

156. Commission Regulation (EC) No 450/2009 of 29 May 2009 on Active and Intelligent Materials and Articles Intended to Come into Contact with Food (Text with EEA Relevance); EC: Brussels, Belgium, 2009.

157. Topuza, F.; Uyarb, T. Antioxidant, antibacterial and antifungal electrospun nanofibers for food packaging applications. Food Res. Int. 2019, 130, 108927. [CrossRef]

158. Callaghan, K.A.O.; Kerry, J.P. Consumer attitudes towards the application of smart packaging technologies to cheese products. Food Packag. Shelf Life 2016, 9, 1-9. [CrossRef]

159. Agriopoulou, S. Active packaging for food applications. EC Nutr. 2016, 6, 86-87.

160. Conte, A.; Angiolillo, L.; Mastromatteo, M.; Del Nobile, M.A. Technological Options of Packaging to Control Food Quality. In Food Industry; Muzzalupo, I., Ed.; InTech: Houston, TX, USA, 2013. [CrossRef]

161. Kerry, J. Smart Packaging Technologies for fast Moving Consumer Goods; John Wiley: Hoboken, NJ, USA, 2008; ISBN 9780470753699.

162. Wilson, C.L. (Ed.) Intelligent and Active Packaging for Fruits and Vegetables; CRC Press: Boca Raton, FL, USA, 2007 ; ISBN 0849391660.

163. Smithers. Future of Active and Intelligent Packaging IMarket Reports and Trends|Smithers. Available online: https: //www.smithers.com/services/market-reports/packaging/the-future-of-active-and-intelligent-packaging (accessed on 19 January 2022).

164. Vilela, C.; Kurek, M.; Hayouka, Z.; Röcker, B.; Yildirim, S.; Antunes, M.D.C.; Nilsen-Nygaard, J.; Pettersen, M.K.; Freire, C.S.R. A concise guide to active agents for active food packaging. Trends Food Sci. Technol. 2018, 80, 212-222. [CrossRef]

165. Yildirim, S.; Röcker, B. Chapter 7-Active Packaging. In Nanomaterials for Food Packaging: Properties, Processing and Regulation; Cerqueira, M.A.P.R., Lagaron, J.M., Pastrana Castro, L.M., de Oliveira Soares Vicente, A.A.M., Eds.; Elsevier: Saint Louis, MO, USA, 2018; pp. 173-202. ISBN 978-0-323-51271-8.

166. Berryman, P. Advances in Food and Beverage Labelling: Information and Regulations; Woodhead Publishing: London, UK, 2014; ISBN 9781782420934.

167. Wikström, F.; Verghese, K.; Auras, R.; Olsson, A.; Williams, H.; Wever, R.; Grönman, K.; Pettersen, M.K.; Møller, H.; Soukka, R. Packaging Strategies That Save Food: A Research Agenda for 2030. J. Ind. Ecol. 2018, 23, 532-540. [CrossRef]

168. Directive 2012/19/EU of the European Parliament and of the Council of 4 July 2012 on Waste Electrical and Electronic Equipment (WEEE) Text with EEA Relevance; EU: Brussels, Belgium, 2012.

169. Licciardello, F. Packaging, blessing in disguise. Review on its diverse contribution to food sustainability. Trends Food Sci. Technol. 2017, 65, 32-39. [CrossRef]

170. Salminen, A.; Latva-Kala, K.; Randell, K.; Hurme, E.; Linko, P.; Ahvenainen, R. The effect of ethanol and oxygen absorption on the shelf-life of packed sliced rye bread. Packag. Technol. Sci. 1996, 9, 29-42. [CrossRef]

171. Upasen, S.; Wattanachai, P. Packaging to prolong shelf life of preservative-free white bread. Heliyon 2018, 4, e00802. [CrossRef] 
172. Antunez, P.D.; Omary, M.B.; Rosentrater, K.; Pascall, M.; Winstone, L. Effect of an Oxygen Scavenger on the Stability of Preservative-Free Flour Tortillas. J. Food Sci. 2011, 77, S1-S9. [CrossRef]

173. Balaguer, M.P.; Lopez-Carballo, G.; Catala, R.; Gavara, R.; Hernandez-Munoz, P. Antifungal properties of gliadin films incorporating cinnamaldehyde and application in active food packaging of bread and cheese spread foodstuffs. Int. J. Food Microbiol. 2013, 166, 369-377. [CrossRef]

174. Chang, Y.; Lee, S.-H.; Na, J.H.; Chang, P.-S.; Han, J. Protection of Grain Products from Sitophilus oryzae (L.) Contamination by Anti-Insect Pest Repellent Sachet Containing Allyl Mercaptan Microcapsule. J. Food Sci. 2017, 11, 2634-2642. [CrossRef]

175. Carpena, M.; Nuñez-Estevez, B.; Soria-Lopez, A.; Garcia-Oliveira, P.; Prieto, M.A. Essential Oils and Their Application on Active Packaging Systems: A Review. Resources 2021, 10, 7. [CrossRef]

176. López-Gómez, A.; Navarro-Martínez, A.; Martínez-Hernández, G.B. Active Paper Sheets Including Nanoencapsulated Essential Oils: A Green Packaging Technique to Control Ethylene Production and Maintain Quality in Fresh Horticultural Products-A Case Study on Flat Peaches. Foods 2020, 9, 1904. [CrossRef] [PubMed]

177. Huang, Y.; Mei, L.; Chen, X.; Wang, Q. Recent Developments in Food Packaging Based on Nanomaterials. Nanomaterials 2018, 8, 830. [CrossRef]

178. Agriopoulou, S.; Stamatelopoulou, E.; Skiada, V.; Varzakas, T. Nanobiotechnology in Food Preservation and Molecular Perspective. In Nanotechnology-Enhanced Food Packaging; Parameswaranpillai, J., Krishnankutty, R.E., Jayakumar, A., Rangappa, S.M., Siengchin, S., Eds.; Wiley-VCH: Weinheim, Germany, 2022; pp. 327-359. ISBN 978-3-527-82770-1.

179. Ariyarathna, I.R.; Rajakaruna, R.; Karunaratne, D.N. The rise of inorganic nanomaterial implementation in food applications. Food Control 2017, 77, 251-259. [CrossRef]

180. Tarazona, A.; Gómez, J.V.; Gavara, R.; Mateo-Castro, R.; Gimeno-Adelantado, J.V.; Jiménez, M.; Mateo, E.M. Risk management of ochratoxigenic fungi and ochratoxin A in maize grains by bioactive EVOH films containing individual components of some essential oils. Int. J. Food Microbiol. 2018, 269, 107-119. [CrossRef] [PubMed]

181. Mateo, E.M.; Gómez, J.V.; Domínguez, I.; Gimeno-Adelantado, J.V.; Mateo-Castro, R.; Gavara, R.; Jiménez, M. Impact of bioactive packaging systems based on EVOH films and essential oils in the control of aflatoxigenic fungi and aflatoxin production in maize. Int. J. Food Microbiol. 2017, 254, 36-46. [CrossRef] [PubMed]

182. Alhendi, A.; Choudhary, R. Current practices in bread packaging and possibility of improving bread shelf life by nano-technology. Int. J. Food Sci. Nutr. Eng. 2013, 3, 55-60.

183. Sharma, C.; Dhiman, R.; Rokana, N.; Panwar, H. Nanotechnology: An Untapped Resource for Food Packaging. Front. Microbiol. 2017, 8, 1735. [CrossRef]

184. Metak, A.M.; Ajaal, T.T. Investigation on Polymer Based Nano-Silver as Food Packaging Materials. Int. J. Chem. Mol. Eng. 2013, 7, 1103-1109. [CrossRef]

185. Metak, A.M. Effects of nanocomposite based nano-silver and nano-titanium dioxide on food packaging materials. Int. J. Appl. Sci. Technol. 2015, 5, 26-40.

186. European Commission. Commission Directive 2007/19/EC of 30 March 2007 amending Directive 2002/72/EC Relating to Plastic Materials and Articles Intended to Come into Contact with Food and Council Directive 85/572/EEC Laying Down the List of Simulants to be Used for Testing Migration of Constituents of Plastic Materials and Articles Intended to Come into Contact with Foodstuffs; EC: Brussels, Belgium, 2007.

187. Avella, M.; De Vlieger, J.J.; Errico, M.; Fischer, S.; Vacca, P.; Volpe, M.G. Biodegradable starch/clay nanocomposite films for food packaging applications. Food Chem. 2005, 93, 467-474. [CrossRef]

188. Echegoyen, Y.; Nerin, C. Nanoparticle release from nano-silver antimicrobial food containers. Food Chem. Toxicol. 2013, 62, 16-22. [CrossRef] [PubMed]

189. Rešček, A.; Ščetar, M.; Hrnjak-Murgić, Z.; Dimitrov, N.; Galić, K. Polyethylene/Polycaprolactone Nanocomposite Films for Food Packaging Modified with Magnetite and Casein: Oxygen Barrier, Mechanical, and Thermal Properties. Polym. Technol. Eng. 2016, 55, 1450-1459. [CrossRef]

190. Peter, A.; Mihaly-Cozmuta, L.; Mihaly-Cozmuta, A.; Nicula, C.; Ziemkowska, W.; Basiak, D.; Danciu, V.; Vulpoi, A.; Baia, L.; Falup, A.; et al. Changes in the microbiological and chemical characteristics of white bread during storage in paper packages modified with $\mathrm{Ag} / \mathrm{TiO}_{2}-\mathrm{SiO}_{2}, \mathrm{Ag} / \mathrm{N}-\mathrm{TiO}_{2}$ or $\mathrm{Au} / \mathrm{TiO}_{2}$. Food Chem. 2016, 197, 790-798. [CrossRef]

191. Agarwal, A.; Raheja, A.; Natarajan, T.; Chandra, T. Effect of electrospun montmorillonite-nylon 6 nanofibrous membrane coated packaging on potato chips and bread. Innov. Food Sci. Emerg. Technol. 2014, 26, 424-430. [CrossRef]

192. Melini, V.; Melini, F. Strategies to Extend Bread and GF Bread Shelf-Life: From Sourdough to Antimicrobial Active Packaging and Nanotechnology. Fermentation 2018, 4, 9. [CrossRef]

193. Gutiérrez, L.; Batlle, R.; Andújar, S.; Sánchez, C.; Nerín, C. Evaluation of Antimicrobial Active Packaging to Increase Shelf Life of Gluten-Free Sliced Bread. Packag. Technol. Sci. 2011, 24, 485-494. [CrossRef]

194. Muizniece-Brasava, S.; Dukalska, L.; Murniece, I.; Dabina-Bicka, I.; Kozlinskis, E.; Sarvi, S.; Santars, R.; Silvjane, A. Active Packaging Influence on Shelf Life Extension of Sliced Wheat Bread. Int. J. Nutr. Food Eng. 2012, 6, 480-486. [CrossRef]

195. Opara, U.L. A review on the role of packaging in securing food system: Adding value to food products and reducing losses and waste. AJAR 2013, 8, 2621-2630. [CrossRef]

196. Wells, J.H.; Singh, R.P. Response characteristics of full-history time-temperature indicators suitable for perishable food handling. J. Food Process. Preserv. 1988, 12, 207-218. [CrossRef] 
197. Floros, J.D.; Newsome, R.; Fisher, W.; Barbosa-Cánovas, G.V.; Chen, H.; Dunne, C.P.; German, J.B.; Hall, R.L.; Heldman, D.R.; Karwe, M.V.; et al. Feeding the World Today and Tomorrow: The Importance of Food Science and Technology. Compr. Rev. Food Sci. Food Saf. 2010, 9, 572-599. [CrossRef] [PubMed]

198. Lillford, P.; Hermansson, A.-M. Global missions and the critical needs of food science and technology. Trends Food Sci. Technol. 2020, 111, 800-811. [CrossRef] 